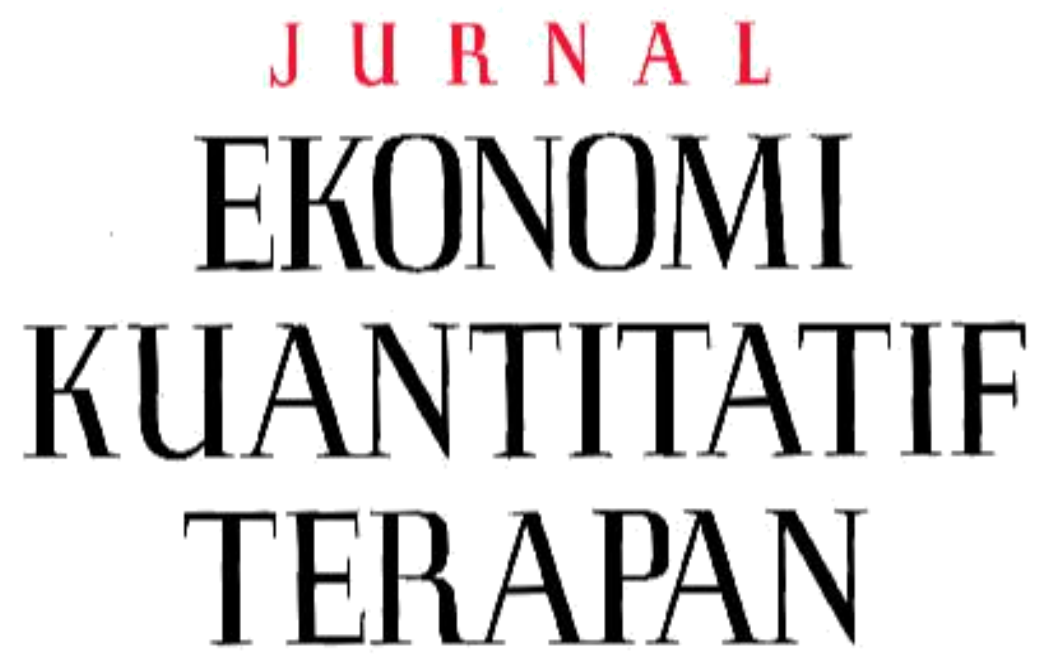

Kebijakan Fiskal Dalam Trend [embangunan Ekonomi Jangka Panjang di Indonesia I Komang Gde Bendesa, Ni Putu Wiwin Setyari

Dampak Pengeluaran Wisatawan Mancanegara terhadap Perekonomian Indonesia: Andhiny Adyaharjanti, Djoni Hartono

Analisis Efek Penularan Melalui Pendekatan Risiko Sistemik dan Keterkaitan Keuangan: Studi Pada DualBanking System di Indonesia Setyo Tri Wahyudi, Rihana Sofie Nabella, Ghozali Maski

Elastisitas Permintaan Gandum dan Produk Turunan Gandum di Indonesia Saaroh Nisrina Saajidah, I Wayan Sukadana

Peran Riset dan Pengembangan (R\&D) Akademis Terhadap Pertumbuhan Ekonomi Abdul Khaliq

Apakah Pendidikan Tinggi Meningkatkan Kemungkinan untuk Bekerja di Sektor Formal?: Bukti dari Data SAKERNAS Rizky Maulana

Pekerja Anak di Indonesia : Peran Penawaran dan Permintaan Keternagakerjaan Resa Surya Utama, Dwini Handayani

Faktor Eksternal dan Internal Penentu Kekuasaan Perempuan Bali Dalam Pengambilan Keputusan Rumah Tangga di Provinsi Bali Putu Ayu Pramitha Purwanti

Willingness To Pay (WTP) Iuran Pemberdayaan LPD kepada Lembaga Pemberdayaan LPD (LPLPD) di Kecamatan Bangli dan Kecamatan Susut Kabupaten Bangli (Pendekatan Ekonomi Kelembagaan) I Nengah Kartika, I Made Jember

Pola Perilaku Komuter dan Stres: Bukti dari Jabodetabek Gema Akbar Riadi, Muhammad Halley Yudhistira 


\section{J U R N A L \\ EKONOMI \\ KUANTITATIF \\ TERAPAN}

VOLUME $13 \quad$ NO.1 FEBRUARI 2020

\section{SUSUNAN REDAKSI}

EDITOR

I Wayan Sukadana

Ni Putu Wiwin Setyari

Anak Agung Ketut Ayuningsasi

DEWAN EDITOR

I Komang Gde Bendesa

Anak Agung Istri Ngurah Marhaeni

Luh Gede Meydianawathi

Ni Made Tisnawati

MITRA BESTARI

Adrianus Amheka, Politeknik Negeri Kupang

Made Antara, Universitas Udayana

Mohammad Arsyad, Universitas Hasanudin

Kadek Dian Sutrisna Artha, Universitas Indonesia

Djoni Hartono, Universitas Indonesia

Palupi Lindiasari, Universitas Indonesia

Devanto Shasta Pratomo, Universitas Brawijaya

Deniey Adi Purwanto, Institut Pertanian Bogor

Ni Made Sukartini, Universitas Airlangga

Setyo Tri Wahyudi, Universitas Brawijaya

Muhammad Halley Yudhistira, Universitas Indonesia

ADMINISTRASI DAN DISTRIBUSI

I Ketut Suadnyana

Ida Ayu Made Widnyani

Jurnal Ekonomi Kuantitatif Terapan diterbitkan oleh

Program Studi Ekonomi Pembangunan

Fakultas Ekonomi dan Bisnis Universitas Udayana

dua kali dalam setahun bulan Februari Dan Agustus

ALAMAT

Ruang Jurnal, Gedung BJ lantai 3

Fakultas Ekonomi dan Bisnis Universitas Udayana

Jalan PB Sudirman Denpasar

Phone: +62-361-255511/ Fax: +62-361-223344

E-mail: jekt@unud.ac.id

http://ojs.unud.ac.id/index.php/jekt

ISSN : 
Jurnal Ekonomi Kuantitatif Terapan (JEKT) adalah jurnal yang menerapkan double blind review pada setiap artikel yang diterbitkan. JEKT diterbitkan oleh Program Studi Ekonomi Pembangunan Fakultas Ekonomi dan Bisnis Universitas Udayana dua kali dalam setahun yaitu bulan Februari dan Agustus. JEKT diterbitkan sebagai kelanjutan dari Jurnal Input, Jurnal Sosial dan Ekonomi. Input terbit berkala sebanyak dua kali dalam setahun, dengan Nomor ISSN 1978-7871, dan di tahun kelima, INPUT telah terbit sebanyak sembilan edisi, dengan terbitan terakhirnya adalah Volume V, Nomor 1 Februari 2012. Pembaharuan INPUT menjadi JEKT tercetus pada pertemuan antara tim redaksi jurnal jurusan bersama pimpinan kampus, awal Maret 2012. Setelah melakukan beberapa evaluasi dan dengan merujuk kepada Peraturan Direktur Jenderal Pendidikan Tinggi Kementrian Pendidikan Nasional Republik Insonesia Nomor 49/dikti/kep/2011 tentang Pedoman Akreditasi Terbitan Berkala Ilmiah, maka terbitlah jurnal jurusan : Jurnal Ekonomi Kuantitatif Terapan dimulai dari Volume V, Nomor 2 Agustus 2012.

Jurnal Ekonomi Kuantitatif Terapan (JEKT) beralamat di Ruang Jurnal, Gedung Program Ekstensi Lantai 1, Fakultas Ekonomi dan Bisnis Universitas Udayana. Jalan PB Sudirman Denpasar, Phone: +62-361-255511/Fax: +62-361-223344. Proses registrasi dan submit artikel dapat dilakukan melalui http://ojs. unud.ac.id/index.php/jekt. Untuk bantuan teknis, penulis dapat menghubungi, email: jekt@unud.ac.id, SMS dan WA : +6281338449077.

Berdasarkan Surat Keputusan Direktur Jenderal Penguatan Riset dan Pengembangan Kementerian Riset, Teknologi, dan Pendidikan Tinggi Nomor 36a/E/KPT/2016 tanggal 23 Mei 2016, JEKT dinyatakan telah terakreditasi B oleh Dikti. Selain terakreditasi oleh Dikti, JEKT juga telah terindeks pada Google Scholar, IPI, dan DOAJ. 


\section{J U R N A L \\ EKONOMI \\ KUANTITATIF \\ TERAPAN}

\section{VOLUME 13 NO.1 FEBRUARI2020}

\section{PENGANTAR REDAKSI}

Pembaca yang terhormat,

Sampai dengan edisi ini terbit, jika pembaca menelusuri deretan jurnal-jurnal yang terdaftar di Sinta dengan kata kunci penelusuran "kuantitatif", maka yang akan muncul adalah Jurnal Ekonomi Kuantitatif (JEKT). Dengan menjadi satu-satunya jurnal dengan fokus kuantitatif, maka JEKT dituntut untuk menampilkan terbitan dengan menggunakan pendekatan kuantitatif. Kalangan peneliti ekonomi, pembangunan dan ilmu sosial lainnya di Indonesia tentunya sudah tidak asing lagi dengan penerapan metode kuantitatif dalam melakukan analisis, khususnya analisis empiris. Terlepas dari semua itu, diatas segala kemutakhiran metode kuantitatif yang digunakan, "ceritera" yang mampu menarik pembaca dan tentunya para pembuat kebijakan untuk berpastisipasi aktif dalam membaca dan menulis di JEKT adalah yang utama. Rangkaian "ceritera" yang baik dan metode kuantitatif yang sesuai tidak akan bermakna jika data yang digunakan tidak transparan dan tidak valid.

Slogan menarik mengenai data digunakan oleh BPS, "Data Mencerdaskan Bangsa", JEKT berkomitmen untuk berperan aktif dalam mewujudkan slogan tersebut menjadi kenyataan. Meskipun tidak selalu data yang digunakan artikel yang dipublikasi oleh JEKT menggunakan data BPS sebagai "menu" utama dalam analisisnya, data BPS pasti hampir selelu menjadi rujukan dalam setipa artikel dalam terbitan JEKT. Pentingnya satu pemahaman dan satu sumber dalam data memegang peran penting dalam analisis dan diskusi yang akan melahirkan implikasi kebijakan yang lebih tepat sasaran. Dalam edisi kali ini, JEKT kembali menerbitkan 10 artikel dengan sumber dan jenis data serta metodologi yang beragam.

Sumber data yang digunakan oleh penulis dalam edisi ini cukup bervariasi mulai sumber data sekunder sampai data primer. Artikel dengan sumber data sekunder sendiri juga memiliki variasi jenis data yang beragam mulai dari data mikro antara lain dari sumber BPS seperti Sakernas, seperti yang digunakan oleh Maulana untuk menjelaskan bagaimana pendidikan menentukan status pekerjaan pekerja dan Susenas serta Podes seperti yang digunakan oleh Utama dalam menjelaskan keberadaan pekerja anak di Indonesia. Sumber data mikro lain, yaitu IFLS digunakan oleh Saajadah dan Sukadana dalam mengungkapkan elastisitas permintaan gandum dan produk turunannya. Data sumber sekunder mengenai keuangan juga ditampilkan dalam edisi kali ini, Wahyudi, et.al, menjelaskan perilaku sistemik dalam industri perbankan dengan menggunakan berbagai data keuangan yang bersumber dari berbagai lembaga keuangan di Indonesia seperti OJK, BI dan sumber online Yahoo finance. 
Tidak hanya analisis mikro, edisi kali ini juga menampilkan berbagai analisis makro dengan menggunakan data sumber sekunder. Hartono, menjelaskan efek pengeluaran wisatawan dengan menggunakan data Input-output. Analisis dengan data agregate ditampilkan oleh Bendesa dan Setyari dalam menjelaskan tren pembangunan jangka panjang di Indonesia. Data publikasi BPS lainnya digunakan oleh Riyadi dan Yudhistira dalam menganalisis perilaku komuter di Jabodetabek. Artikel dengan sumber data primer juga diterbitkan dalam edisi kali ini. Purwanti dan Kartika adalah dua diantaranya, kedua penulis ini menggunakan data primer untuk menganalisis ekonomi lokal di Bali. Purwanti, menjelaskan bagaimana peran perempuan Bali dalam pengambilan keputusan rumah tangga, sedangkan Kartika menganalisis willingness to pay masyarakat lokal setempat pada lembaga keuangan lokal Bali, LPD.

Akhir kata, redaksi menyimpulkan bahwa artikel-artikel yang diterbitkan oleh JEKT mulai mengalami pergeseran sejak kemunculannya pertama kali lebih dari 10 tahun silam, utamanya dari sisi data yang digunakan. Semakin banyak artikel-artikel yang menampilkan analisis dengan menggunakan data mikro baik dari sumber sekunder maupun primer. Meskipun demikian JEKT tetap membuka diri untuk artikel-artikel dengan penggunaan data agregate. Kembali ke Alenia pembuka di atas, yang terpenting bagi JEKT dalam terbitannya adalah "ceritera" yang menarik, metode kuantitatif yang sesuai dan data yang valid. 


\title{
KEBIJAKAN FISKAL DALAM TREND PEMBANGUNAN EKONOMI JANGKA PANJANG INDONESIA
}

\author{
I Komang Gde Bendesa \\ Ni Putu Wiwin Setyari \\ Fakultas Ekonomi dan Bisnis Universitas Udayana
}

\section{ABSTRAK}

Peranan pajak dalam membiayai pembangunan ekonomi Indonesia sangat dominan dan semakin penting. Bahkan dalam sejarahnya, peranan pajak pada saat suatu pemerintahan dibangun sudah dilaksanakan dalam berbagai bentuk, seperti pungutan pada sektor pertanian, perdagangan dan lainnya. Meskipun peranan pajak penting, namun tingkat penerimaan pajak di Indonesia masih tergolong rendah. Fokus pemerintah pada pembangunan infrastruktur sangat beralasan karena infratsruktur ndonesia masih kurang disamping kualitasnya masih buruk. Dengan perbaikan dan pembangunan inffrastruktur diharapkan pertumbuhan ekonomi meningkat.

Penelitian ini akan menganalisis peranan pajak dalam pembangunan Indonesia, khususnya selama dua dekade. Peranan pajak dapat dilihat dalam periode yang berbeda, yaitu sebelum krisis dan setelah krisis tahun 1998. Peranan pajak dalam kebijakan fiskal terkait dengan variabel makro lainnya, seperti suku bunga, nilai tukar, perdagangan luar negeri, dan anggaran pemerintah. Dengan mengaitkan peran pajak dengan variabel ini maka dihasilkan rekomendasi bagi pembangunan Indonesia, khususnya peran pajak dalam dua periode berbeda.

Kata kunci: kebijakan fiskal, pertumbuhan ekonomi, kebijakan makro dalam perekonomian terbuka

Klasifikasi JEL: E62, E66, F41

\section{FISCAL POLICY IN LONG TERM INDONESIAN ECONOMICS GROWTH}

\begin{abstract}
The role of taxes in financing Indonesia's economic development is very dominant and increasingly important. Even in its history, the role of taxes when a government was built has been carried out in various forms, such as levies in the agriculture, trade and others. Although the role of tax is important, the level of tax revenue in Indonesia is still relatively low. The focus of the government on infrastructure development is very reasonable because Indonesian infrastructure is still lacking despite the poor quality. With the improvement and development of infrastructure, economic growth is expected to increase.
\end{abstract}


This research will analyze the role of tax in Indonesia's development, especially for two decades. The role of taxes can be seen in different periods, namely before the crisis and after the crisis of 1998. The role of taxes in fiscal policy is related to other macro variables, such as interest rates, exchange rates, foreign trade, and government budgets. Linking the role of tax to this variable results in recommendations for Indonesia's development, specifically the role of tax in two different periods.

Kata kunci: fiscal policy, economics growth, open economy macroceonomics Klasifikasi JEL: E62, E66, F41

\section{PENDAHULUAN}

Pertumbuhan ekonomi Indonesia yang ditargetkan $5,6 \%$ pada tahun 2016 kemungkinan besar tidak terpenuhi sehingga harus direvisi menjadi sekitar 5,1\%. Sejak 2013 pertumbuhan ekonomi didorong oleh dua factor utama, yaitu investasi dan konsumsi domestik (Brodjonegoro, 2013). Persoalan yang dihadapi Indonesia adalah apabila target pajak sebesar Rp1.546,7 triliun yang merupakan $85 \%$ dari pendapatan negara tidak terpenuhi, sehingga dapat dipastikan sasaran pembangunan tidak akan tercapai. Pendapatan negara sebesar Rp1.822,5 triliun digunakan untuk membiayai belanja negara sebesar Rp2.095,7 triliun, sehingga terjadi deficit anggaran sebesar Rp273,2 triliun atau $2,15 \%$ dari PDB yang masih dalam kategori aman karena berada dibawah ambang batas kritis 3\% (Treasury, 2016).

Pendapatan negara berasal dari penerimaan dalam negeri dan hibah, dimana penerimaan dalam negeri sebagian besar bersumber dari perpajakan dan sebagian kecil dari penerimaan negara bukan pajak seperti ditunjukkan pada Tabel 1 . Sumber pajak berasal dari pajak penghasilan (PPh), pajak pertambahan nilai (PPn), pajak bumi dan bangunan (PBB), bea perolehan hak atas tanah dan bangunan (BPHTB), cukai dan pajak lainnya. Sumber pajak yang terbesar berasal dari PPh Non Migas (53\%) dan PPn $(42 \%)$, dan laainnya hanya $5 \%$. Penerimaan perpajakan sejak 20102016 bertumbuh rata-rata 13,5\%, dengan pertumbuhan tertinggi terjadi pada tahun $2015(29,9 \%)$ dan tahun 2011 (20,8\%).Beberapa kebijakan yang dilakukan untuk mencapai target perpajakan adalah: mengoptimalisasikan pemeriksaan untuk menghindari transfer pricing dan fraud; melakukan ekstensifikasi dan intensifikasi wajib pajak; dan, mengimplementasikan tahun 2016 sebagai tahun penegakan hukum.

Disamping itu, pemerintah juga berencana melakukan pengampunan pajak (tax amnesty) kepada mereka yang sebelumnya membangkang membayar pajak, sehingga apabila kebijakan ini disetujui oleh lembaga legislatif pada bulan Juni ini maka dana yang dapat dikumpulkan dari pajak diperkirakan mencapai Rp165 triliun. Dengan kebijakan tax amnesty, untuk tahuntahun berikutnya penerimaan pajak akan bertambah karena asset dari pengampunan pajak meningkat, sehingga pajak pendapatan juga akan meningkat. Yang dikenakan pajak adalah pendapatan dari asset yang dipulangkan kembali oleh pengemplang pajak setelah mereka 
membayar $2-4 \%$ dari nilai asset yang dimiliki sebagai pengganti pajak yang tidak dibayar selama mereka tidak membayar pajak.

\begin{tabular}{|c|c|c|c|c|}
\hline \multicolumn{5}{|c|}{ Tabel 1. Postur APBN Tahun Anggaran 2018 (Rp Triliun) } \\
\hline & $\begin{array}{r}2016 \\
\text { LKPP }\end{array}$ & $\begin{array}{r}2017 \\
\text { LKPP } \\
\end{array}$ & $\begin{array}{c}2018 \\
\text { OUTLOOK } \\
\end{array}$ & $\begin{array}{c}2019 \\
\text { APBN } \\
\end{array}$ \\
\hline A. Pendapatan Negara & 1555.9 & 1666.4 & 1903 & 2165.1 \\
\hline I. PENDAPATAN DALAM NEGERI & 1549.9 & 1654.7 & 1897.6 & 2164.7 \\
\hline 1. PENERIMAAN PERPAJAKAN & 1285 & 1343.5 & 1548.5 & 1786.4 \\
\hline Tax Ratio (\%) & 0.01 & 0.01 & 11.57 & 12.22 \\
\hline al. PPH Migas & 666.2 & 646.8 & 761.2 & 894.4 \\
\hline 2. PENERIMAAN NEGARA BUKAN PAJAK & 262 & 311.2 & 349.2 & 378.3 \\
\hline II. PENERIMAAN HIBAH & 9 & $\mathbf{1 1 . 6}$ & 5.4 & 0.4 \\
\hline B. Belanja Negara & 1864.3 & 2007.4 & 2217.3 & 2461.1 \\
\hline I. BELANJA PEMERINTAH PUSAT & 1154 & 1265.4 & 1453.6 & 1634.3 \\
\hline 1. Belanja K/L & 684.2 & 765.1 & 813.5 & 855.4 \\
\hline 2. Belanja Non K/L & 469.8 & 500.2 & 640.2 & 778.9 \\
\hline I. TRANSFER KE DAERAH DAN DANA DESA & 710.3 & 742 & 763.6 & 826.8 \\
\hline 1. Transfer ke Daerah & 663.6 & 682.2 & 703.6 & 756.8 \\
\hline 2. Dana Desa & 46.7 & 59.8 & 60 & 70 \\
\hline C. Keseimbangan Primer & -125.6 & -124.4 & -64.8 & -20.1 \\
\hline D. Surplus/ (Defisit) Anggaran (A-B) & -308.3 & -341 & -313.2 & -296 \\
\hline$\%$ Surplus/ (Defisit) Anggaran terhadap PDB & -2.49 & -2.51 & -2.12 & -1.84 \\
\hline E. Pembiayaan Anggaran & 334.5 & 366.6 & 314.2 & 296 \\
\hline I. Pembiayaan Utang & 403 & 429.1 & 387.4 & 359.3 \\
\hline II. Pembiayaan Investasi & -89.1 & -59.8 & -65.7 & -75.9 \\
\hline III. Pemberian Pinjaman & 1.7 & -2.1 & 6.5 & 2.4 \\
\hline IV. Kewajiban Penjaminan & -0.7 & -1 & -1.1 & $\mathbf{0}$ \\
\hline V. Pembiayaan Lainnya & 19.6 & 0.4 & 0.2 & 15 \\
\hline
\end{tabular}

Sumber: DJA, Kemenkeu, Informasi APBN 2019

Dalam beberapa bulan terakhir pemerintah (Kementeria Keuangan) sekuat tenaga berusaha meningkatkan penerimaan pajak melalui beberapa cara yang antara lain melalui pengampunan pajak ( $\operatorname{tax}$ amnesty) sampai ekstensifikasi wajib pajak melalui penambahan jumlah NPWP yang disosialisasikan sampai ke sekolah-sekolah. Masyarakat luas bertanya-tanya, kenapa harus membayar pajak dan dipakai untuk apa pajak tersebut? Kenapa tidak menggunakan sumber lain selain pajak yang dirasakan memberatkan masyarakat? Pertanyaan-pertanyaan seperti ini sangat wajar bisa disebabkan karena pengetahuan masyarakat yang masih kurang atau karena kesadaran untuk membayar pajak memang rendah. Sebagai contoh, bila seseorang bepergian untuk mengunjungi keluarga atau rekan bisnis ke suatu tempat dengan mengendarai motor atau mobil atau kendaraan lainnya, maka orang tersebut tidaklah mungkin membuat jalan sendiri-sendiri untuk mencapai tujuannya, karena membuat jalan sebagai milik sendiri atau barang privat akan menjadi terlalu mahal. Mereka bisa menggunakan jalan umum sebagai barang publik yang disediakan oleh pemerintah, yang pembangunannya dibiayai oleh pemerintah yang bersumber dari pajak. Perekonomian akan menjadi lebih efisien. 
Alasan lain kenapa pajak diperlukan antara lain: untuk memberikan penghasilan kepada pemerintah, meredistribusikan kekayaan dari masyarakat kaya kepada masyarakat miskin, dan untuk menghindari eksternalitas negative akibat pembangunan. Uang yang diperoleh dari hasil pajak digunakan untuk membiayai pembangunan, seperti: jembatan, jalan, irigasi, taman kota, sekolah, lembaga pemasyarakatan, membayar gaji polisi, tentara, pegawai negeri, hakim, jaksa, membayar telpon, listrik dan fax pemerintah, membiayai perjalanan dinas pegawai pemerintah, menyediakan bea siswa murid dan mahasiswa yang sekolah di dalam dan luar negeri, biaya memburu pemakai narkoba, biaya pensiun dan dana kesehatan yang dikenal dengan BPJS, dan lainnya yang setidaknya membiayai fungsi minimal pemerintah di bidang penegakan hukum, pendidikan, kesehatan, dan keamanan bagi masyarakat.

$$
\text { Pajak juga bisa }
$$

mendistribusikan kekayaan dari si kaya kepada si miskin. Dalam pembangunan, tidak setiap warga dapat melakukan kegiatan yang bisa memberikan penghasilan yang sama, bahkan meskipun melakukan kegiatan ekonomi yang sama namun penghasilan mereka bisa berbeda. Perbedaan ini bisa disebabkan karena faktor endowment atau faktor bawaan yaitu dari kelahirannya mereka sudah berbeda, seperti mereka yang terlahir dari keluarga kaya dan ada yang dari keluarga miskin, ada yang terlahir sehat dan ada yang cacat. Disamping itu, kesempatan yang diperoleh juga bisa karena perolehan pendidikan berbeda, faktor koneksi yang sering disebut jejaring, geografi dimana umumnya mereka yang berasal dari desa memiliki kesempatan lebih rendah, dan tentunya juga kultur. Perbedaan ini bisa membuat gap ekonomi yang mencolok antara si kaya dan miskin, bahkan yang kaya bisa semakin kaya dan yang miskin semakin miskin. Untuk mengatasi kesenjangan ini, pajak dapat diandalkan peranannya apabila dilaksanakan dengan baik. Pemerintah bertindak seolah-oleh seperti Robin Hood, mengambil dari yang kaya untuk diberikan pada yang miskin, melalui penetapan pajak progresif, dan juga subsidi seperti subsidi bahan bakar.

Dalam proses pembangunan banyak terjadi dampak negatif terutama pada penggunaan barang publik yang dikenal dengan eksternalitas negatif. Pembangunan jalan baru sering harus mengorbankan pemandangan alam indah yang dinikmati oleh masyarakat, lalu lintas yang ramai mengakibatkan polusi dan berdampak buruk bagi saluran pernafasan, pembuangan sampah yang sembarangan dan tidak terkelola dengan baik berdampak buruk bagi kesehatan. Untuk mengatasi ini pemerintah harus campur tangan karena umumnya masyarakat tidak mau tahu dengan akibat yang ditimbulkan, karena setiap orang berpikir bahwa apa yang dilakukannya hanyalah bagian yang sangat kecil dari keseluruhan, sehingga bisa diabaikan. Membuat satu puntung rokok tidaklah ada artinya bagi keseluruhan volume sampah. Untuk membiayai ini 
pemerintah perlu dana yang diperoleh dari pajak.

Dari alasan tersebut, pajak telah memainkan peran yang sangat penting dalam pembangunan, tanpa pajak mustahil pembangunan dapat terlaksana terutama yang menyangkut pembangunan barang publik yang tersedia bagi seluruh lapisan masyarakat. Karenanya, pengelolaan pajak beserta administrasinya berkembang terus dan penegakan hukum bagi yang membangkang membayar pajak, terutama di negara maju, semakin tegas. Seperti yang disampaikan oleh Benjamin Franklin, politisi dan Founding Father Amerika yang terlahir 17 Januari 1706: “Di dunia ini tidak ada sesuatu yang pasti, kecuali kematian dan pajak. Meskipun demikian, golongan liberalis secara prinsip menolak pemungutan pajak karena tindakan itu dipandang sebagai pengekangan kebebasan seseorang.

Besaran pajak sebagai pendapatan negara masih tergolong rendah bila dibandingkan dengan ebesar 5,5\% (Bank Dunia, 2015). negara tetangga di Asia bila menggunakan ukuran tax ratio (ratio pajak dengan Gross Domestic Product). Tax ratio Indonesia hanyalah 11,4\% pada tahun 2013, dan ditargetkan $12,2 \%$ pada tahun 2016. Gambar 1 menunjukkan bahwa negara-negara maju memiliki tax ratio yang cukup besar, seperti Jerman (36\%), Jepang $(34,7 \%)$, Inggris $(32,9 \%)$, dan AS $(25,4 \%)$. China juga memiliki tax ratio yang tinggi sebesar $19,4 \%$ dan ini salah satu yang bisa menjelaskan kenapa perekonomian China berkembang pesat dan pemerintahnya juga kuat dalam mengimplementasikan kebijakannya. Indonesia bahkan berada dibawah Filipina yang memiliki angka tax ratio yang lumayan lebih tinggi sebesar $12,9 \%$.

Rendahnya tax ratio akan memicu lambannya pertumbuhan ekonomi. Seperti disampaikan di atas pertumbuhan ekonomi direvisi menjadi 5,1\% yang sebelumnya Bank Dunia memprediksi pertumbuhan pada tahun 2016

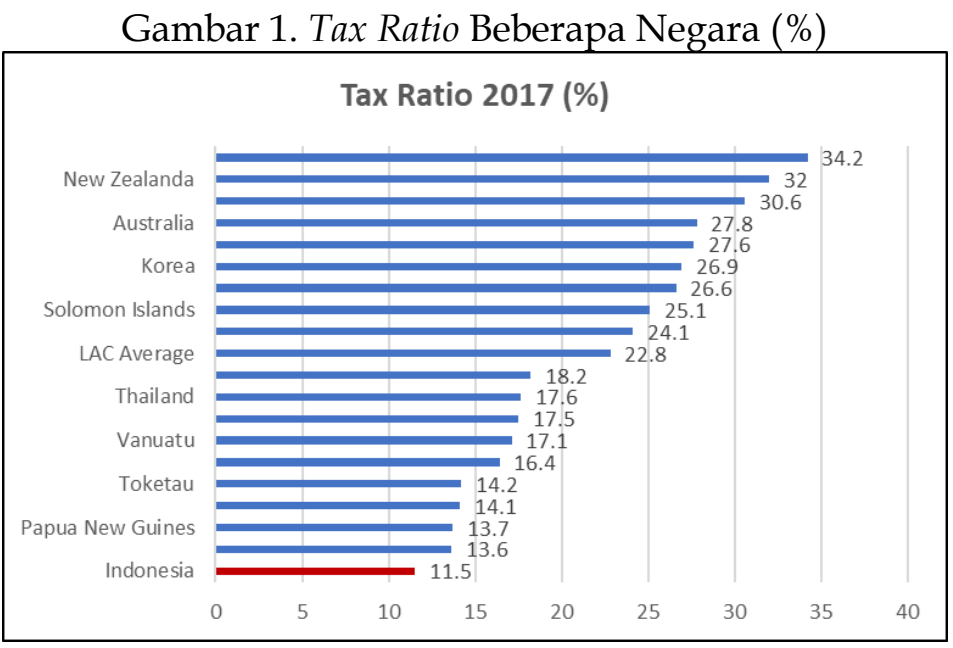

Selain tax ratio, indikator lainnya yang dapat digunakan untuk membandingkan posisi relatif suatu negara dalam kemampuan 
penduduknya membayar pajak adalah pajak per kapita, yaitu jumlah pajak suatu negara dibagi dengan jumlah penduduk. Sedangkan pendapatan per kapita adalah jumlah pendapatan suatu Negara yang diukur dari Gross Domestic Productnya dibagi dengan jumlah penduduk. Ke dua ukuran ini memiliki arah yang sama sebab pendapatan yang tinggi menunjukkan kemampuan membayar pajak juga tinggi. Seperti ditunjukkan pada Tabel 2, pajak per kapita Indonesia sangat rendah yaitu US\$396,2 pada tahun 2013, sedikit lebih tinggi dari Filipina. Meskipun Filipina memiliki pajak per kapita lebih rendah namun tax ratio-nya lebih tinggi dari Indonesia hal mana merefleksikan implementasi penegakan hukum pembayaran pajak lebih baik atau memang masyarakatnya sudah lebih sadar untuk membayar pajak.

Negara-negara maju seperti Jerman, Jepang, Amerika dan Inggris memiliki pajak per kapita yang tinggi. Pajak digunakan sesuai fungsi dan sasaran pembangunan sehingga Negara-negara ini tergolong makmur. Jerman misalnya, tergolong welfare state yang menerapkan sistem perpajakan sangat baik dan menggunakan pajaknya untuk kesejahteraan penduduknya. Layanan public sangat bagus, seperti layanan kesehatan, pendidikan, transportasi, pension, dan lainnya. Misalnya, mahasiswa perguruan tinggi milik pemerintah tidak perlu membayar uang kuliah, perlakuan layanan kesehatan bagi setiap warga sama. Indonesia dengan program BPPJS-nya sudah mulai memperhatikan layanan publik bagi semua warganya meskipun belum memadai seperti yang ideal di negara maju, disebabkan karena pajak yang diterima pemerintah relatif masih rendah seperti yang ditunjukkan oleh indikator tax ratio dan pajak per kapita.

Tabel 2. Pendapatan/Kapita dan Pajak/Kapita di Beberapa Negara, dalam US dolar Tahun 2018

\begin{tabular}{clrr}
\hline Urutan & Negara & Pajak/Kapita & Pendapatan/Kapita \\
\hline 1 & Norway & $40,747.1$ & 74,356 \\
2 & Luxembourg & $38,947.3$ & 106,705 \\
3 & Ireland & $24,265.8$ & 78,785 \\
4 & Netherlands & $22,440.4$ & 56,383 \\
5 & Switzerland & $17,972.4$ & 64,649 \\
6 & United States & $16,966.2$ & 62,606 \\
7 & Singapore & $14,249.0$ & 100,345 \\
8 & Qatar & $2,870.5$ & 130,475 \\
9 & Indonesia & $1,587.6$ & 13,230 \\
10 & Kuwait & $1,005.0$ & 67,000 \\
11 & United Arab Emirates & 971.3 & 69,382 \\
\hline
\end{tabular}

Sumber: B I dan BPS, be be rapa terbitan, data diolah.

Penerimaan pajak yang rendah juga bisa disebabkan karena kegiatan ekonomi tidak semuanya "masuk pasar" sehingga kegiatan yang dilakukan tidak termasuk dalam perhitungan. Tidak dimasukkannya 
dalam perhitungan bisa disebabkan karena ketidaktahuan atau kesengajaan. Kegiatan seperti ini tergolong dalam ekonomi bawah tanah (underground ekonomi) atau ekonomi bayangan (shadow ekonomi). Misalnya, tukang servis AC dengan tariff layanan Rp150.000 sekali kerja (1-2 jam), bisa memperoleh pendapatan Rp300.000 perhari atau Rp6 juta per bulan dengan 20 hari kerja, atau Rp70 juta setahun, suatu penghasilan di atas minimum batas kena pajak. Namun, penghasilan ini tidak dilaporkan karena mungkin mereka tidak tahu atau tidak mau tahu. Kegiatan seperti ini bisa terjadi di semua sektor ekonomi, seperti sektor informal, sektor formal dimana yangbersangkutan mencari pekerjaan tambahan, dan sebagainya. Ekonomi bawah tanah terjadi di negara berkembang dan juga di negara maju. Mankiw (2015) menyampaikan besaran ekonomi bawah tanah sebagai persentase terhadap Gross Domestic Product di Bolivia mencapai $68 \%$, Thailand $54 \%$, Australia 13\%, Inggris 12\%, Jepang 11\%, dan Amerika 8\%. Di Indonesia, menurut Chatib Basri (Nizar dan Purnomo), besaran ekonomi bayangan sekitar 40\%. Ini berarti pemerintah harus lebih keras lagi bekerja sebab persoalan pajak cukup komplek, yang penting harus ada kepastian seperti yang diucapkan oleh Benyamin Franklin: di dunia hanya kematian dan pajak yang pasti.

Pembangunan ekonomi selain dipengaruhi oleh stimulus pajak juga dipengaruhi oleh shok eksternal seperti model yang dikembangkan oleh Azwar dan Tyers, 2015). Mereka menemukan bahwa eksternal factor Asian Financial Crisis dan Global
Financial Crisis berpengaruh nyata pada pembangunan ekonomi, yang salah satu temuannya adalah bahwa ekspansi fiscal dilaksanakan oleh pemerintah agar inflasi dapat dihindari. Untuk mempertahankan pertumbuhan dan pembangunan seperti yang direncanakan, Siwage Dharma Negara (2016) menyarankan agar mengoptimalkan anggaran melalui pemungutan pajak dan eksekusi anggaran yang efektif, serta penghematan pengeluaran. Laporan IMF (2015) juga menyebutkan bahwa akibat shok eksternal Indonesia sangat rentan terhadap resiko fiskal. Resiko tersebut antara lain: ketergantungan pada dana asing meningkat, penurunan harga minyak akan mengurangi penerimaan negara, pengeluaran untuk kesehatan dan pension bisa terganggu. Untuk menghindari resiko tersebut maka pemerintah disarankan mengambil kebijakan "prudent design and management of fiscal policy will remain essential". Dengan demikian peran pajak sangat penting, bukan hanya dalam jumlah tetapi juga pengelolaannya.

Castro dan Camarillo (2014) dalam studinya tentang factor-faktor yang menentukan penerimaan pajak di Negara-negara anggota ORCD berpendapat bahwa Negara-negara dengan GDP tinggi, kontribusi yang rendah pada FDI, dan sektor industry yang maju, serta adanya proteksi bagi kebebasan individu cenderung memiliki penerimaan pajak yang tinggi. Sedangkan Karagoz (2013) dalam penelitiannya di Turki tentang faktor penentu penerimaan pajak menggunakan analisa regresi runtun waktu menggunakan beberapa variable, yaitu: kontribusi sektor 
pertanian, industry, utang negara, monetisasi keuangan, tingkat urbanisasi, dan keterbukaan negara tersebut terhadap luar.Hasilnya menunjukkan bahwa sumbangan sektor pertanian negative terhadao penerimaan pajak yaitu sesuatu yang memang diharapkan karena pajak diharapkan dating dari sektor nonpertanian. Disamping itu, ternyata kerterbukaan di Turki tidak membawa pengaruh pada penerimaan pajak.

Bikas dan Andrukaite (2013) menggunakan nilai tambah pajak untuk melihat apakah penerimaan pajak dapat ditingkatkan. Penelitiannya menggunakan dua puluh delapan negara Uni Eropa selama periode 2001-2012. Variabel yang digunakan adalah GDP, biaya konsumsi, ekspor, pendapatan, dan pendapatan per kapita. Hasil penelitiannya menemukan bahwa hanya pendapatan per kapita yang dapat meningkatkan nilai tambah pajak.sdapun tujuan penelitian ini adalah untuk menjawab pertanyaan utama: apakah kebijakan fiskal khususnya perpajakan mampu mendorong pertumbuhan ekonomi Indonesia.

\section{METODE PENELITIAN}

Penelitian ini menggunakan data time-series dair berbagai sumber. Teknik analisis yang digunakan adalah analisa kuantitatif untuk bisa memprediksi peranan pajak terhadap pembangunan yang diukur dari pertumbuhan ekonomi, dan menguji hipotesa, yang meliputi beberapa proses.

Proses stokastik stasioner
Data time series yang digunakan dibentuk oleh stochastic atau random process dan data yang dipakai untuk menaksir disebut realization. Perbedaan antara random process dan realization serupa dengan perbedaan antara populasi dan sampel.

Sifat-sifat proses dalam keadaan stasioner adalah:

$$
\begin{aligned}
& \text { Mean } \quad: E\left(Y_{t}\right)=\mu \\
& \text { Variance } \quad: \\
& \operatorname{var}\left(Y_{t}\right)=E\left(Y_{t}-\mu\right)^{2}=\sigma^{2} \\
& \text { Covariance }: \\
& \gamma_{k}=E\left[\left(Y_{t}-\mu\right)\left(Y_{t+k}-\mu\right)\right] \\
& \text { Bila } \mathrm{k}=0 \text {, diperoleh } \gamma_{0} \text { yaitu sama } \\
& \text { dengan varian } \mathrm{Y}\left(\sigma^{2}\right) . \\
& \text { Bila } \mathrm{k}=1 \text {, diperoleh } \gamma_{1} \text { yaitu sama } \\
& \text { dengan kovarian antara nilai } \mathrm{Y} .
\end{aligned}
$$

\section{Random Walk with Drift.}

Persamaan dimodifikasi menjadi sebagai berikut:

$$
Y_{t}=\delta+Y_{t-1}+\mu_{t}
$$

Dimana $\delta$ adalah parameter drift. Nama drift berasal dari fakta apabila kita menulis persamaan sebelumnya sebagai:

$$
Y_{t}-Y_{t-1}=\Delta Y_{t}=\delta+\mu_{t}
$$

persamaan ini menunjukkan bahwa $Y_{t}$ drift (bergerak) naik atau turun tergantung pada nilai $\delta$ yang positif atau negatif.

Dengan mengikuti prosedur pada random walk without drift, maka dapat ditunjukkan model untuk random walk with drift sebagai berikut.

$$
\begin{aligned}
& E\left(Y_{t}\right)=Y_{0}+t . \delta \\
& \operatorname{var}\left(Y_{t}\right)=t \sigma^{2}
\end{aligned}
$$

Proses Stokastik Tren Stasioner (TS) dan Perbedaan Stasioner (DS).

Perbedaan antara proses stokastik stasioner dan nonstasioner 
menjadi penting mengingat apakah tren observasi atau serangkaian ekonomi aktual bersifat deterministic atau stochastic. Secara umum, apabila tren dalam time series sepenuhnya dapat diprediksi dan tidak variabel, maka tren itu disebut tren deterministic, sedangkan apabila tidak dapat diprediksi dia disebut tren stokastik.

Model time series sebagai berikut:

$$
Y_{t}=\beta_{1}+\beta_{2} t+\beta_{3} Y_{t-1}+u_{t}
$$

Dimana $\mathrm{u}_{\mathrm{t}}$ adalah white noise error term dan $\mathrm{t}$ diukur secara kronologis. Kemungkinan yang kita miliki adalah pure random walk, random walk with drift, deterministic trend, random walk with drift and deterministic trend, dan deterministic trend with stationary component, sebagai berikut:

\section{Pure random walk}

Apabila pada persamaan (12) $\beta_{1}=0, \beta_{2}=0, \beta_{3}=1$, akan diperoleh:

$$
Y_{t}=Y_{t-1}+u_{t}
$$

yaitu tiada lain daripada RWM without drift, karenanya nonstasioner. Tetapi apabila persamaan di atas ditulis sebagai:

$$
\Delta Y_{t}=\left(Y_{t}-Y_{t-1}\right)=u_{t}
$$

maka persamaan tersebut menjadi stasioner. Karenanya, RWM without drift merupakan a difference staionary process (DSP).

\section{Random walk with drift}

Apabila dalam persamaan

(12) $\beta_{1} \neq 0, \beta_{2}=0, \beta_{3}=1$, akan diperoleh:

$$
Y_{t}=\beta_{1}+Y_{t-1}+u_{t}
$$

yaitu RWM with drift, karenanya nonstasioner. Apabila persamaan di atas ditulis sebagai:

$$
\left(Y_{t}-Y_{t-1}\right)=\Delta Y_{t}=\beta_{1}+u_{t}
$$

ini berarti $\mathrm{Yt}$ akan menunjukkan tren yang positif $\left(\beta_{1} \succ 0\right)$ atau negatif $\left(\beta_{1} \prec 0\right)$. Tren ini disebut stochastic trend.

\section{Deterministic trend}

Apabila dalam persamaan (12) $\quad \beta_{1} \neq 0, \beta_{2} \neq 0, \beta_{3}=0, \quad$ akan diperoleh:

$$
Y_{t}=\beta_{1}+\beta_{2} t+u_{t}
$$

yang disebut trend stationary process (TSP). Meskipun rata-rata $Y_{t}$ adalah $\beta_{1}+\beta_{2} t$, yang mana tidak konstan, tetapi variannya $\left(=\sigma^{2}\right)$ konstan. Apabila nilai $\beta_{1}$ dan $\beta_{2}$, maka rata-rata dapat di prediksi dengan sempurna. Karenanya, apabila kita kurangkan rata-rata $Y_{t}$ dari $\mathrm{Y}_{\mathrm{t}}$, hasilnya adalah stasioner, sehingga disebut trend stationary. Prosedur menghilangkan tren (deterministic) ini disebut detrending.

4. Random walk with drift and deterministic trend

Apabila dalam persamaan (12) $\beta_{1} \neq 0, \beta_{2} \neq 0, \beta_{3}=1$, akan diperoleh:

$$
Y_{t}=\beta_{1}+\beta_{2} t+Y_{t-1}+u_{t}
$$

Yaitu RWM with drift dan a deterministic trend, yang dapat dilihat apabila persamaan ini ditulis sebagai berikut:

$$
\Delta Y_{t}=\beta_{1}+\beta_{2} t+u_{t}
$$

yang berarti $Y_{t}$ adalah stasioner.

Dalam penelitian ini digunakan tiga model, yaitu model 1, 2, dan 4 . 
Deterministic trend with stationary AR(1) component

Apabila dalam persamaan $\beta_{1} \neq 0, \beta_{2} \neq 0, \beta_{3} \prec 1$, akan diperoleh:

$$
Y_{t}=\beta_{1}+\beta_{2} t+\beta_{3} Y_{t-1}+u_{t}
$$

yaitu stasioner sekitar tren deterministik.

\section{Pengujian hipotesa stasioner}

Jenis tes yang digunakan untuk mendeteksi stasioner adalah sbb:

1. Autocorrelation Function (ACF) dan Correlogram.

Satu tes sederhana daripada stasioner didasarkan pada apa yang disebut autocorrelation function (ACF). ACF pada lag k, ditandai oleh $k$, adalah:

$$
\begin{aligned}
& \rho_{k}=\frac{\gamma_{k}}{\gamma_{0}} \\
& \rho_{k}=\frac{\text { covariancepadalag } k}{\text { variance }}
\end{aligned}
$$

\section{Tes Unit Root}

Tes stasionaritas dan nontasionaritas yang sangat populer adalah unit root test. Proses tes unit root ditunjukkan sebagai berikut.

$$
Y_{t}=\rho Y_{t-1}+\mu_{t} \quad-1 \leq \rho \leq 1
$$

dimana $u_{t}$ adalah white noise error term. Seperti telah dijelaskan diatas, bahwa apabila $\rho=1$, yaitu kasus unit root, persamaan menjadi RWM without drift, yaitu proses stokastik nonstasioner. Dengan demikian, ide daripada tes unit root adalah meregresi $\mathrm{Y}_{\mathrm{t}}$ dengan $\mathrm{Y}_{\mathrm{t}-1}$ dan menghitung apakah $\rho$ secara statsitik signifikan sama dengan satu. Untuk alasan teoritis, persamaan dimanipulasi dengan mengurangi ke dua sisi dengan $\mathrm{Y}_{\mathrm{t}-1}$ sehingga diperoleh sebagai berikut:

$$
\begin{gathered}
Y_{t}-Y_{t-1}=\rho Y_{t-1}-Y_{t-1}+\mu_{t} \\
=(\rho-1) Y_{t-1}+\mu_{t} \\
\Delta Y_{t}=\delta Y_{t-1}+\mu_{t}
\end{gathered}
$$

dimana $\delta=(\rho-1)$ dan $\Delta$ adalah firstdifference operator.

Tes hipotesa (nol) bahwa $\delta=0$. Apabila $\delta=0$, maka $\rho=1$, yaitu kita mempunyai unit root, yang berarti time series adalah nonstasioner.

Jadi, dari persamaan di atas, yang kita lakukan adalah pertama, mencari perbedaan pertama dalam $\mathrm{Y}_{\mathrm{t}}\left(\Delta \mathrm{Y}_{\mathrm{t}}=\mathrm{Y}_{\mathrm{t}}-\mathrm{Y}_{\mathrm{t}}\right.$ 1), berikutnya, meregresikan $\Delta Y_{t}$ dengan $\mathrm{Y}_{\mathrm{t}-1}$. Kemudian perhatikan apakah koefisien slope daripada regresi $(=\hat{\delta})$ apakh nol ataukah tidak. Apabila koefisiennya nol, maka kita simpulkan bahwa $Y_{t}$ adalah nonstasioner. Tetapi, apabila negatif, kita simpulkan bahwa $Y_{t}$ adalah stasioner.

Untuk men tes ini kita tidak dapat menggunakan tes $t$ yang biasa karena tidak mengikuti distribusi $t$ meskipun sampelnya berukuran besar, yaitu tidak mempunyai distribusi normal. Alternatif yang digunakan adalah $\tau$ (tau) statistic atau tau test yang dikenal dengan Dickey-Fuller (DF) test. Prosedur aktual dalam menerapkan tes DF melibatkan beberapa keputusan,yaitu tes DF di estimasi dalam tiga bentuk yang berbeda dan tiga hipotesa nol yang berbeda pula, sebagai berikut.

$Y_{t}$ adalah random walk:

$$
\Delta Y_{t}=\delta Y_{t-1}+\mu_{t}
$$

$\mathrm{Y}_{\mathrm{t}}$ adalah random walk with drift :

$$
\Delta Y_{t}=\beta_{1}+\delta Y_{t-1}+\mu_{t}
$$

$\mathrm{Y}_{\mathrm{t}}$ adalah random walk with drift

sekitar

$$
\underset{\Delta Y_{t}=\beta_{1}+\beta_{2} t+\delta Y_{t-1}+\mu_{t}}{\text { tren }}
$$

dimana:

$\mathrm{Y}$ adalah pajak dan $\mathrm{t}$ adalah waktu atau variabel tren. Dalam setiap persamaan di 
atas, hipotesa nol adalah $\delta=0$; yaitu unit root, time series adalah nonstasioner. Hipotesa alternatif adalah $\delta<0$, yaitu time series adalah stasioner.

Apabila hipotesa nol ditolak, berarti:

1. $Y_{t}$ adalah stasioner dengan ratarata nol, untuk persamaan,

2. $\mathrm{Y}_{\mathrm{t}}$ adalah stasioner dengan ratarata tidak nol $\left[=\beta_{1} /(1-\rho)\right]$,

3. $Y_{\mathrm{t}}$ adalah stasioner di sekitar tren deterministik untuk persamaan.

Prosedur estimasi adalah sebagai berikut.

Hipotesa yang ditetapkan adalah sebagai berikut:

$H_{0}: \delta=0$, yaitu, unit root, time series adalah stasioner.

$H_{1}: \delta \prec 0$, yaitu, time series adalah nonstasioner.

Kriteria peneremiaan dan penolakan hipotesa:

Apabila $|\tau| \succ D F|\tau|$, maka tolak $\mathrm{H}_{0}$; jadi time series adalah stasioner.

Apabila $|\tau| \prec D F|\tau|$, maka $\mathrm{H}_{0}$

jangan ditolak; jadi time series adalah nonstasioner.

Pengujian Augmented Dickey-Fuller (ADF)

Dalam melakukan tes DF pada persamaan di atas, diasumsikan bahwa error term $\mu_{t}$ tidak terkorelasi. Tetapi dalam hal $\mu_{t}$ terkorelasi, Dickey dan Fuller telah mengembangkan suatu tes, dikenal dengan the augmented DickeyFuller (ADF) test. Ini dilakukan dengan memperbanyak (augmenting) ke tiga persamaan tersebut dengan menambah nilai lag daripada variabel dependen $\Delta \mathrm{Y}_{\mathrm{t}}$. Dengan menggunakan persamaan berikut.

$$
\Delta Y_{t}=\beta_{1}+\beta_{2} t+\delta Y_{t-1}+\mu_{t}
$$

Tes ADF disini dilakukan dengan mengestimasi regresi berikut.

$$
\Delta Y_{t}=\beta_{1}+\beta_{2} t+\delta Y_{t-1}+\alpha_{i} \sum_{i=1}^{m} \Delta Y_{t-i}+\varepsilon_{t}
$$

dimana $\varepsilon_{\mathrm{t}}$ adalah pure white noise error term dan $\Delta Y_{t-1}=Y_{t-1}-Y_{t-2}$, $\Delta Y_{t-2}=Y_{t-2}-Y_{t-3}$, dan seterusnya. Jumlah lag perbedaan $\left(\Delta Y_{t}\right)$ yang akan dimasukkan dalam persamaan sering ditentukan secara empiris, yaitu idenya adalah dengan memasukkan jumlah lag perbedaan yang cukup pada persamaan dimana error term menjadi tidak terkorelasi. Pada tes ADF yang di tes adalah apakah $\delta=0$.

\section{Kointegrasi}

Regresi time series nonstasioner pada time series nonstasioner lainnya dapat menghasilkan regresi spurious. Untuk itu harus dilakukan tes koin tegrasi dengan meregresikan pajak (Pajak) pada pendapatan (PDB) sebagai berikut:

$$
\text { Pajak }_{t}=\beta_{1}+\beta_{2} P D B_{t}+\mu_{t}
$$

Persamaan ini dapat ditulis:

$$
\mu_{t}=\text { Pajak }_{t}-\beta_{1}-\beta_{2} P D B_{t}
$$

\section{Tes Kointegrasi}

Dua cara yang dapat dilakukan untuk tes kointegrasi adalah: 1 . Tes unit root DF atau ADF terhadap residual yang di estimasi dari regresi yang di kointegrasikan, dan 2. Tes cointegrating regression Durbin-Watson (CRDW).

Engle-Granger (EG) or Augmented EngleGranger (AEG) Test.

Dalam menerapkan tes DF atau ADF, pertama estimasi regresi pada persamaan (33), dapatkan residual dari regresi tersebut, dan gunakan tes DF atau ADF. Tetapi, karena u yang diestimasi didasarkan pada parameter kointegrasi yang diestimasi, $\beta_{2}$, maka nilai signifikansi daripada DF dan ADF tidak begitu tepat. Karenanya Engle dan Granger telah menghitung nilai kritis ini 
yang dikenal dengan tes Engle-Granger (EG) dan augmented Engle-Granger (AEG).

Karena pajak (Y) dan pendapatan (PDB) secara individual nonstasioner, maka ada kemungkinan regresi ini spurious yaitu hubungan keduanya lebih disebabkan karena tren. Untuk itu, kita regresikan perbedaan pertama residual dengan lag residual, yang persamaannya dapat ditulis sebagai berikut.

$$
\mu_{t}=\beta_{1} u_{t-1}+v_{t}
$$

dimana:

$$
\beta_{1}=1 \text { menunjukkan }
$$

nonkointegrasi, dan

$$
-1<\quad \beta_{1}<1 \quad \text { menunjukkan }
$$

kointegrasi

Dengan mengurangi $\mathrm{u}_{\mathrm{t}-1}$ dari ke dua sisi persamaan di atas maka persamaan tersebut dapat ditulis sebagai berikut

$$
\Delta \mu_{t}=\beta_{1} u_{t-1}+v_{t}
$$

$$
\begin{aligned}
& \operatorname{dimana} \gamma=\beta_{1}-1 \\
& \mathrm{H}_{0}: \beta_{1}=1, \text { yaitu } \gamma=0 \\
& \mathrm{H}_{1}: \beta_{1}<1, \text { yaitu } \gamma<0
\end{aligned}
$$

Alasan yang mendasari hipotesa ini adalah apabila $\beta_{1}>1$, maka regresi akan eksplosif, yaitu nonstasioner.

\section{HASIL DAN PEMBAHASAN}

\subsection{Perkembangan Ekonomi dan Perpajakan di Indonesia \\ Pada tabel 3 ditunjukkan} perkembangan Produk Domestik Bruto atas harga berlaku (PDB HB), Domestik Bruto atas harga konstan (PDB HK), Pertumbuhan PDB, Konsumsi, dan Investasi. Semua data untuk variabel tersebut menunjukkan tren yang meningkat selama dua dekade lebih sejak tahun 1990. Tren ini menggambarkan perkembangan ekonomi makro yang cukup baik. 
mengalami penurunan yang sangat Tabel 3. Produk Domestik Bruto, Konsumsi dan Investasi (dalam Rp Milyar), dan Pertumbuhan PDB Indonesia, 1990-2018

\begin{tabular}{rrrrrr}
\hline \multirow{2}{*}{ Tahun } & PDB HB & \multicolumn{1}{c}{ PDB HK } & Pertumbuhan & PDsumsi (harga berlaku) & Investasi \\
\hline 1990 & $195,597.20$ & $115,217.30$ & 7.24 & $106,312.30$ & $55,633.40$ \\
1991 & $227,450.20$ & $123,225.20$ & 6.95 & $125,035.80$ & $63,893.90$ \\
1992 & $259,884.50$ & $131,184.50$ & 6.46 & $135,880.30$ & $70,820.20$ \\
1993 & $329,775.80$ & $329,775.80$ & 6.5 & $192,958.40$ & $86,667.30$ \\
1994 & $382,219.70$ & $354,640.80$ & 7.54 & $228,119.30$ & $105,380.60$ \\
1995 & $454,514.10$ & $383,792.30$ & 8.22 & $279,876.40$ & $129,217.50$ \\
1996 & $532,568.00$ & $413,797.90$ & 7.82 & $332,094.40$ & $157,652.70$ \\
1997 & $627,695.40$ & $423,245.90$ & 4.7 & $387,170.70$ & $177,686.10$ \\
1998 & $955,753.50$ & $376,375.10$ & -13.13 & $647,826.30$ & $243,043.40$ \\
1999 & $1,099,731.60$ & $379,353.20$ & 0.79 & $813,183.30$ & $221,472.30$ \\
2000 & $1,389,769.90$ & $1,389,769.90$ & 4.92 & $856,798.30$ & $275,881.20$ \\
2001 & $1,646,322.00$ & $1,440,405.70$ & 3.64 & $1,039,655.00$ & $323,875.30$ \\
2002 & $1,821,833.40$ & $1,505,216.40$ & 4.5 & $1,231,964.50$ & $353,967.00$ \\
2003 & $2,013,674.60$ & $1,577,171.30$ & 4.78 & $1,372,078.00$ & $392,788.60$ \\
2004 & $2,295,826.20$ & $1,656,516.80$ & 5.03 & $1,532,888.30$ & $515,381.20$ \\
2005 & $2,774,281.10$ & $1,750,915.20$ & 5.69 & $1,785,596.40$ & $655,854.30$ \\
2006 & $3,339,216.80$ & $1,847,126.70$ & 5.5 & $2,092,655.70$ & $805,786.10$ \\
2007 & $3,950,893.20$ & $1,964,327.30$ & 6.35 & $2,510,503.80$ & $985,627.10$ \\
2008 & $4,948,688.40$ & $2,082,456.10$ & 6.01 & $2,999,956.90$ & $1,370,717.00$ \\
2009 & $5,606,203.40$ & $2,178,850.40$ & 4.63 & $3,290,995.90$ & $1,744,357.10$ \\
2010 & $6,864,133.10$ & $6,864,133.10$ & 6.22 & $3,786,062.90$ & $2,127,840.70$ \\
2011 & $7,831,726.00$ & $7,831,726.00$ & 6.17 & $4,260,075.50$ & $2,451,914.00$ \\
2012 & $8,615,704.50$ & $8,615,704.50$ & 6.03 & $4,768,745.10$ & $2,819,026.50$ \\
2013 & $9,524,736.50$ & $7,524,736.50$ & 5.58 & $5,352,696.50$ & $3,059,780.50$ \\
2014 & $10,569,705.30$ & $8,564,866.60$ & 5.02 & $5,915,194.23$ & $3,436,923.74$ \\
2015 & $11,526,332.80$ & $8,982,517.10$ & 4.88 & $6,490,929.68$ & $3,782,011.86$ \\
2016 & $12,401,728.50$ & $9,434,613.40$ & 5.03 & $7,027,023.46$ & $4,040,201.81$ \\
2017 & $13,587,212.60$ & $9,912,703.60$ & 5.07 & $7,627,573.95$ & $4,370,574.77$ \\
2018 & $14,837,357.50$ & $10,425,316.30$ & 5.17 & $8,269,753.90$ & $4,790,606.99$ \\
\hline
\end{tabular}

Sumber: BI dan BPS, beberapa terbitan, data diolah.

Meskipun demikian data tax ratio (TR) yaitu rasio pajak terhadap PDB menunjukkan fluktuasi yang cukup besar. Demikian pula halnya dengan pertumbuhan PDB pada periode yang sama menunjukkan fluktuasi yang sama, yaitu pada tahun 1998 baik TR maupun pertumbuhan PDB besar, seperti ditunjukkan pada gambar 2. Hubungan yang sama ditunjukkan pada gambar 3, yaitu fluktuasi TR dan pendidikan yang diukur dari persentase penduduk yang berumur diatas 15 tahun yang sedang menempuh pendidikan, memiliki tern yang sama. Hubungan ini menunjukkan bahwa ada 
hubungan yang kuat antara TR dengan pertumbuhan PDB dan pendidikan.

Gambar 2 Tax Ratio (TR) dan Pertumbuhan PDB (g_HK) Indonesia

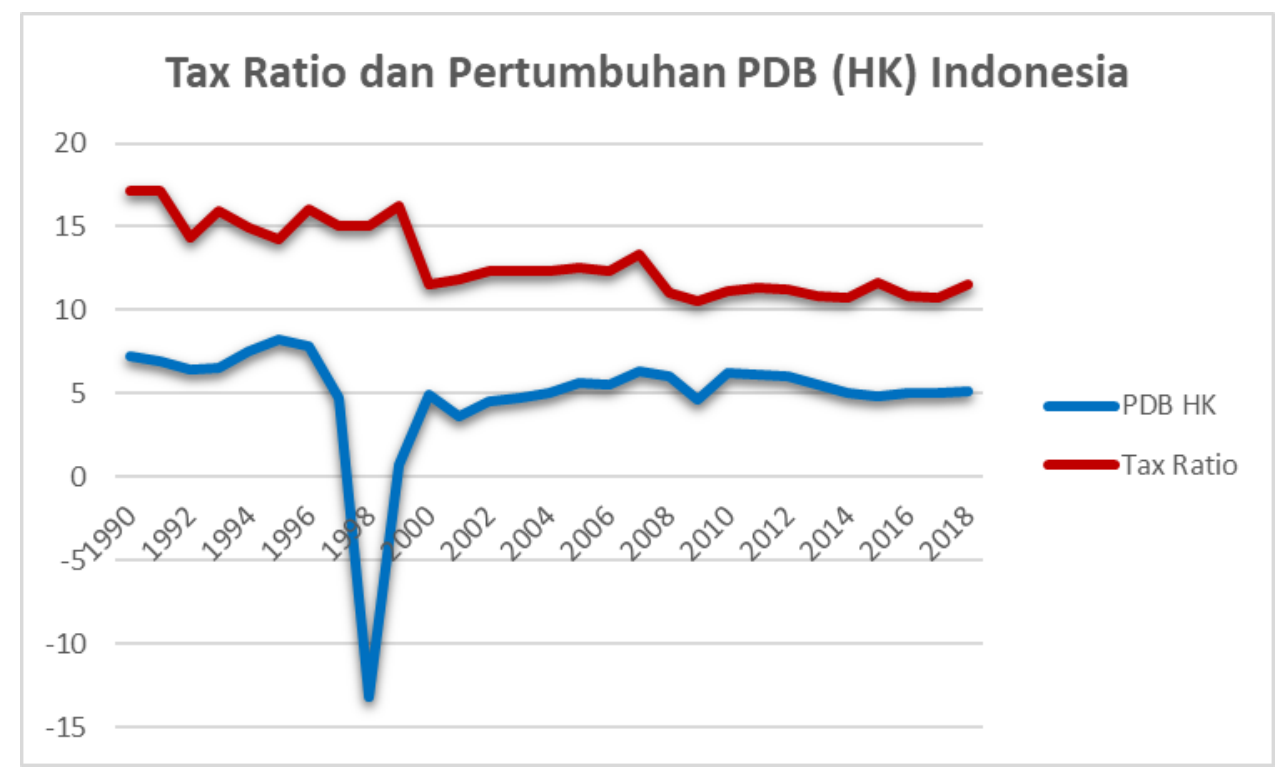

Gambar 3 Tax Ratio (TR) dan Pendidikan (RMP) Indonesia

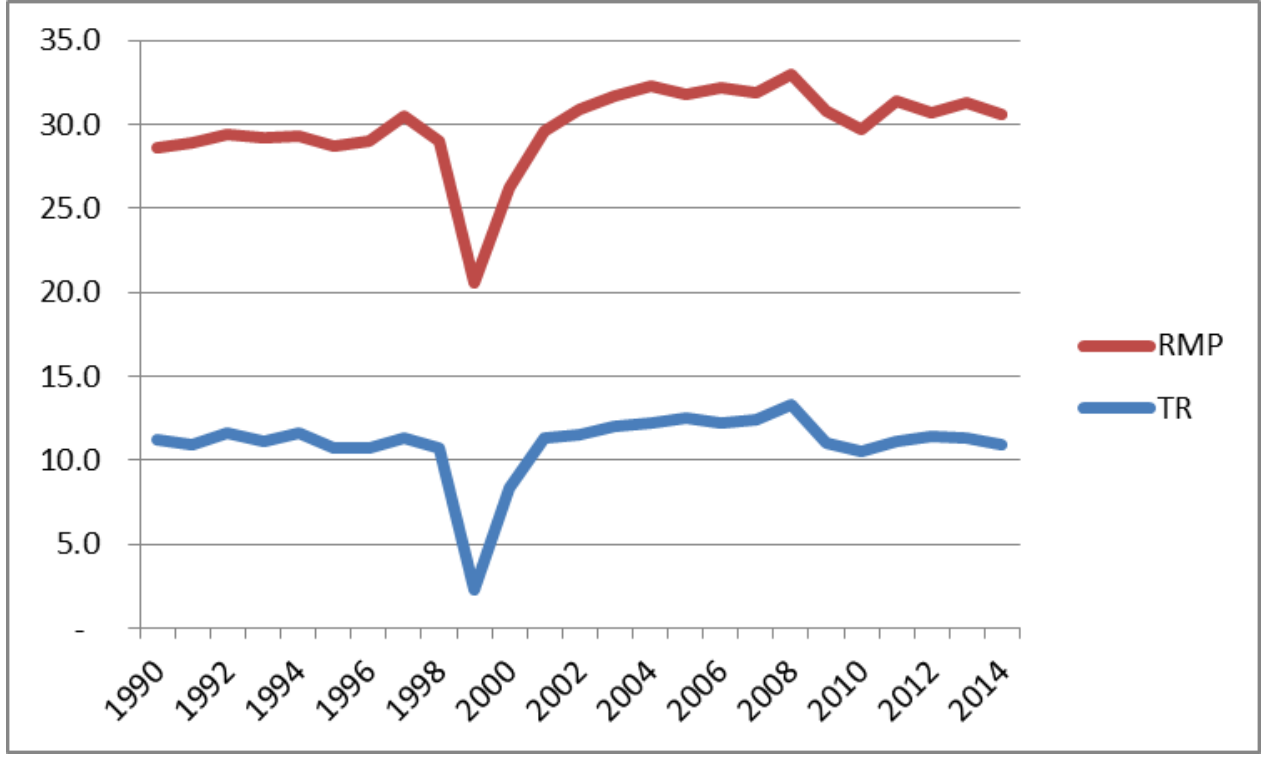

Tabel 4 menunjukkan data agregat Ekspor, Impor, Penerimaan Negara, Pendapatan Negara, dan Pajak pada dua decade lebih sejk tahun 1990. Semua data menunjukkan tren yang meningkat kecuali pada tahun 1999 mengalami penurunan yang sangat drastis yang dipicu oleh situasi politik yang sangat buruk yaitu jatuhnya pemerintahan Suharto pada tahun 1998. Dampak situasi yang buruk tersebut sangat instan karena langsung pada tahun berikutnya terjadi penurunan drastic pada data tersebut. 
Pada tahun 2000 terjadi perubahan yang cukup besar dimana angka-angka agregat yang sebelumnya turun pada tahun 1990, pada tahun berikutnya sudah pulih kembali bahkan meningkat cukup besar pada penermiaan dan pendapatan Negara karena penerimaan pajak meningkat pesat.

Tabel 4. Ekspor, Impor, Penerimaan dan Pendapatan Negara dan Pajak Indonesia, 1990-2018 (dalam Rp milyar)

\begin{tabular}{|c|c|c|c|c|c|}
\hline TAHUN & EKSPOR & IMPOR & $\begin{array}{c}\text { Penerimaan } \\
\text { negara }\end{array}$ & $\begin{array}{c}\text { Pendapatan } \\
\text { negara }\end{array}$ & Pajak \\
\hline 1990 & $51,953.10$ & $50,945.70$ & $42,193.00$ & $42,193.00$ & $22,011.00$ \\
\hline 1991 & $62,263.80$ & $61,375.70$ & $42,582.00$ & $42,582.00$ & $24,919.00$ \\
\hline 1992 & $76,384.40$ & $70,336.60$ & $48,863.00$ & $48,863.00$ & $30,092.00$ \\
\hline 1993 & $88,230.90$ & $78,383.00$ & $56,113.00$ & $56,113.00$ & $36,665.00$ \\
\hline 1994 & $101,331.90$ & $96,952.60$ & $66,418.00$ & $66,418.00$ & $44,442.00$ \\
\hline 1995 & $119,592.50$ & $125,656.90$ & $71,340.00$ & $71,340.00$ & $48,686.00$ \\
\hline 1996 & $137,533.30$ & $140,812.00$ & $86,278.00$ & $86,278.00$ & $57,340.00$ \\
\hline 1997 & $174,871.30$ & $176,599.80$ & $112,924.00$ & $112,924.00$ & $70,934.00$ \\
\hline 1998 & $506,244.80$ & $413,058.10$ & $156,470.00$ & $156,408.00$ & $102,395.00$ \\
\hline 1999 & $390,560.10$ & $301,654.00$ & $42,582.00$ & $42,582.00$ & $24,919.00$ \\
\hline 2000 & $559,490.30$ & $423,317.90$ & $205,334.50$ & $205,334.50$ & $115,912.50$ \\
\hline 2001 & $642,594.30$ & $506,426.20$ & $301,078.00$ & $300,600.00$ & $185,541.00$ \\
\hline 2002 & $595,514.00$ & $480,815.40$ & $298,528.00$ & $298,528.00$ & $210,088.00$ \\
\hline 2003 & $613,720.80$ & $465,940.90$ & $341,396.00$ & $340,928.00$ & $242,048.00$ \\
\hline 2004 & $739,639.30$ & $632,376.10$ & $403,367.00$ & $403,105.00$ & $280,559.00$ \\
\hline 2005 & $945,121.80$ & $830,083.40$ & $495,224.00$ & $493,919.00$ & $347,031.00$ \\
\hline 2006 & $1,036,316.50$ & $855,587.80$ & $637,987.00$ & $636,153.00$ & $409,203.00$ \\
\hline 2007 & $1,162,973.80$ & $1,003,271.30$ & $707,806.00$ & $706,109.00$ & $490,989.00$ \\
\hline 2008 & $1,475,119.10$ & $1,422,902.10$ & $981,609.40$ & $979,305.40$ & $658,700.80$ \\
\hline 2009 & $1,354,409.40$ & $1,197,092.70$ & $848,763.20$ & $847,096.60$ & $619,922.20$ \\
\hline 2010 & $1,667,917.80$ & $1,537,719.80$ & $995,271.40$ & $992,248.40$ & $723,306.60$ \\
\hline 2011 & $2,061,886.20$ & $1,868,075.00$ & $1,210,599.70$ & $1,205,345.80$ & $873,874.00$ \\
\hline 2012 & $2,118,979.00$ & $2,152,937.00$ & $1,338,109.60$ & $1,332,322.90$ & $980,518.10$ \\
\hline 2013 & $2,283,761.00$ & $2,359,212.00$ & $1,438,891.10$ & $1,432,058.60$ & $1,077,306.70$ \\
\hline 2014 & $2,501,202.00$ & $2,580,527.00$ & $1,550,491.00$ & $1,545,456.50$ & $1,146,866.00$ \\
\hline 2015 & $2,438,990.00$ & $2,394,880.00$ & $1,488,200.00$ & $1,491,500.00$ & $1,235,800.00$ \\
\hline 2016 & $2,367,370.00$ & $2,273,530.00$ & $1,555,700.00$ & $1,546,800.00$ & $1,284,900.00$ \\
\hline 2017 & $2,743,060.00$ & $2,605,240.00$ & $1,648,200.00$ & $1,655,800.00$ & $1,339,800.00$ \\
\hline 2018 & $3,110,750.00$ & $3,272,520.00$ & $1,942,300.00$ & $1,928,400.00$ & $1,521,400.00$ \\
\hline
\end{tabular}

\section{Sumber: BI dan BPS, beberapa terbitan, data diolah.}

Pada tabel 5 disajikan data agregat yang terkait kependudukan, yaitu Pengangguran, Penduduk berumur 15 tahun ke atas yang berada dalam bangku sekolah, Proporsi Angkatan Kerja yang menerima pendidikan, Penduduk Bekerja, Rata-rata tahun sekolah tenaga kerja, dan Produktivitas Tenaga Kerja. 
Produktivitas tenaga kerja diperoleh dari membagi pendapatan yang diukur dari produk domestic bruto dengan jumlah penduduk bekerja. Pada tahun 1990, anga produktivitas tenaga kerja rata-rata Rp2,7 dan meningkat menjadi Rp92 juta pada tahun 2014.

Tabel 5. Pengangguran, Pendidikan, Kesempatan Kerja, dan Produktivitas Tenaga Kerja Indonesia,

\begin{tabular}{|c|c|c|c|c|c|c|}
\hline Tahun & $\begin{array}{c}\text { Pengangguran } \\
(\%)\end{array}$ & $\begin{array}{c}\text { Penduduk } \\
\text { dalam bangku } \\
\text { Sekolah }(\%)\end{array}$ & $\begin{array}{c}\text { Angkatan Kerja } \\
\text { dalam Bangku } \\
\text { Sekolah }(\%)\end{array}$ & $\begin{array}{c}\text { Penduduk } \\
\text { Bekerja } \\
\text { (orang) }\end{array}$ & $\begin{array}{c}\text { Produktivitas } \\
\text { Tenaga Kerja } \\
\text { (Rp Juta) }\end{array}$ & $\begin{array}{c}\text { Rata-rata } \\
\text { Tahun } \\
\text { Sekolah }\end{array}$ \\
\hline 1990 & 2.55 & 8.97 & 17.37 & $73,104,538$ & 2.68 & 4.8 \\
\hline 1991 & 2.62 & 8.6 & 17.99 & $73,911,624$ & 3.08 & 4.9 \\
\hline 1992 & 2.74 & 8.21 & 17.83 & $75,891,561$ & 3.42 & 5 \\
\hline 1993 & 2.79 & 8.34 & 18.13 & $76,718,265$ & 4.3 & 5 \\
\hline 1994 & 4.36 & 7.85 & 17.69 & $79,687,230$ & 4.8 & 5.1 \\
\hline 1995 & 4.62 & 8.02 & 17.95 & $81,619,796$ & 5.57 & 5.2 \\
\hline 1996 & 4.87 & 8.19 & 18.19 & $83,552,361$ & 6.37 & 5.4 \\
\hline 1997 & 4.69 & 8.01 & 19.18 & $85,047,007$ & 7.38 & 6.6 \\
\hline 1998 & 5.46 & 8.15 & 18.24 & $87,292,541$ & 10.95 & 6.9 \\
\hline 1999 & 6.36 & 7.75 & 18.33 & $88,816,859$ & 12.38 & 7 \\
\hline 2000 & 6.08 & 7.62 & 17.9 & $89,837,730$ & 15.47 & 7.1 \\
\hline 2001 & 8.1 & 7.57 & 18.37 & $90,807,417$ & 18.13 & 7.2 \\
\hline 2002 & 9.06 & 7.56 & 19.31 & $91,647,166$ & 19.88 & 7.2 \\
\hline 2003 & 9.67 & 7.58 & 19.63 & $92,810,791$ & 21.7 & 7.5 \\
\hline 2004 & 9.86 & 7.52 & 20.06 & $93,722,036$ & 24.5 & 7.5 \\
\hline 2005 & 11.24 & 8.57 & 19.32 & $93,958,387$ & 29.53 & 7.6 \\
\hline 2006 & 10.28 & 8.41 & 19.89 & $95,456,935$ & 34.98 & 7.7 \\
\hline 2007 & 9.11 & 8.39 & 19.49 & $99,930,217$ & 39.54 & 7.7 \\
\hline 2008 & 8.39 & 7.94 & 19.67 & $102,552,750$ & 48.26 & 7.7 \\
\hline 2009 & 7.87 & 8.16 & 19.69 & $104,870,663$ & 53.46 & 7.6 \\
\hline 2010 & 7.14 & 8.14 & 19.16 & $108,207,767$ & 63.43 & 7.8 \\
\hline 2011 & 7.48 & 8.00 & 20.27 & $107,416,309$ & 72.91 & 7.8 \\
\hline 2012 & 6.13 & 8.23 & 19.29 & $112,504,868$ & 76.58 & 7.9 \\
\hline 2013 & 6.17 & 8.13 & 20.02 & $112,761,072$ & 84.47 & 8 \\
\hline 2014 & 5.94 & 9.16 & 19.68 & $114,628,026$ & 91.97 & 8.1 \\
\hline 2015 & 6.18 & 8.99 & 20.53 & $114,819,199$ & 98.12 & 8.32 \\
\hline 2016 & 5.58 & 8.66 & 20.08 & $118,411,973$ & 106.45 & 8.42 \\
\hline 2017 & 5.49 & 8.00 & 20.10 & $121,022,423$ & 113.86 & 8.5 \\
\hline 2018 & 5.33 & 8.07 & 20.23 & $124,004,950$ & 122.15 & 8.58 \\
\hline
\end{tabular}

Sumber: B I dan BPS, beberapa te rbitan, data diolah.

5.2. Pengaruh Pertumbuhan pendapatan yang diperoleh. Semakin Ekonomi pada Pajak

Kemampuan masyarakat membayar pajak tergantung pada tinggi pendapatannya maka besaran pajak juga semakin tinggi. Misalnya, minimum pendapatan yang 
dikenakan pajak adalah Rp45 juta setahun untuk bujangan, yang berarti apabila yangbersangkutan pendapatannya setahun Rp60 juta maka pajak pendapatan yang wajib dibayar adalah Rp15 juta dikalikan $15 \%$. Sedangkan apabila pendapatannya adalah misalnya Rp100 juta maka pajak yang harus dibayar adalah Rp55 juta dikalikan $15 \%$. Ini menunjukkan bahwa makin tinggi pendapatan seseorang maka pajak yang dibayar juga akan semakin tinggi.
Pada tabel 6 ditunjukkan hasil regresi pendapatan terhadap pajak. Angka koefisien yang didapatkan adalah 1,027 dengan tingkat signifikansi 0,00. Angka ini menunjukkan bahwa apabila pendapatan masyarakat naik ratarata $1 \%$ maka pajak akan meningkat sebesar 1,027 persen. Hasil ini juga menunjukkan bahwa pendapatan yang meningkat selama 25 tahun sejak tahun 1990 telah meningkatkan penerimaan pajak secara signifikan.

Tabel 6. Hasil Regresi PDB terhadap Pajak

Dependent Variable: LOG(PAJAK)

\begin{tabular}{crrrl}
\hline \hline Variable & Coefficient & Std. Error & t-Statistic & Prob. \\
C & -2.632310 & 0.775909 & -3.392549 & 0.0025 \\
LOG(PDB_HB) & 1.027121 & 0.054030 & 19.01002 & 0.0000 \\
R-squared & 0.940164 & & & \\
\hline \hline
\end{tabular}

Perkembangan pajak dan pendapatan (PDB) secara grafis ditunjukkan pada gambar 4 dan gambar 5 . Ke dua gambar menunjukkan tren yang positif selama dua decade lebih. Namun, perkembangan pajak lebih berfluktuasi yang menunjukkan bahwa pajak sensitive terhadap perubahan pendapatan.

Gambar 4 Grafik Perkembangan Pajak 1990-2018 


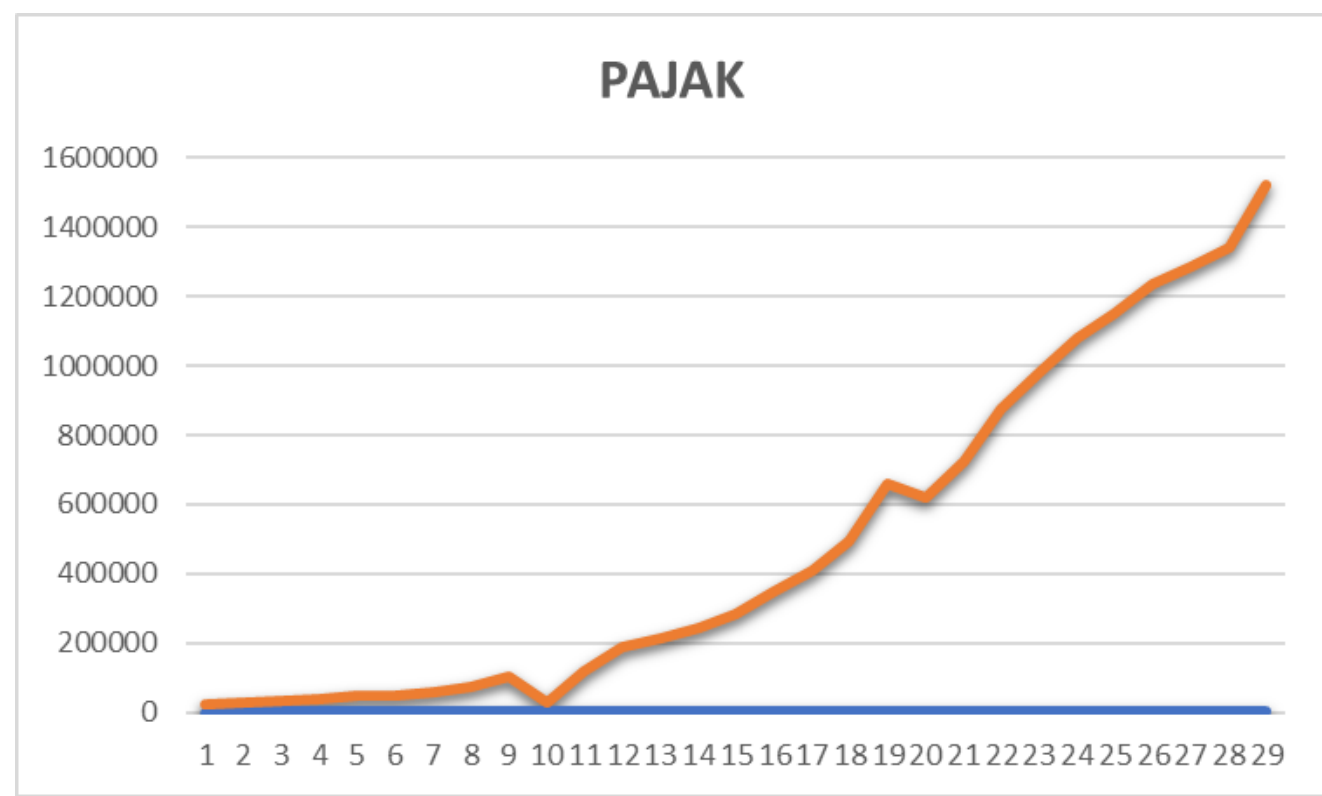

Gambar 5 Grafik Perkembangan PDB 1990-2018

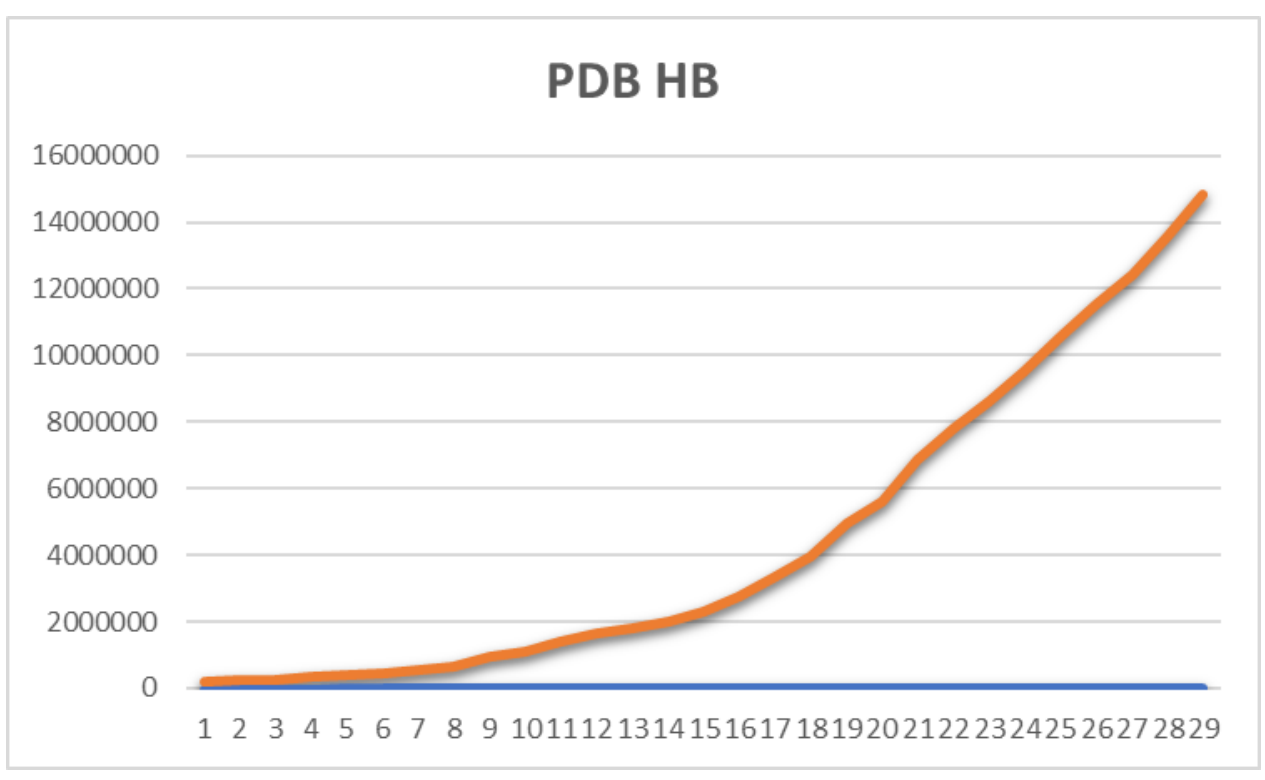

\subsection{Tren PDB, Tren Pajak, dan Tax Ratio}

\section{Tren PDB}

Grafik PDB yang disajikan pada gambar 5 dapat dikuantifikasi dengan menggunakan variabel tren. Seperti ditunjukkan pada tabel 7, variabel tren menunjukkan angka koefisien sebesar 0,173 dan sangat signifikan. Ini menunjukkan bahwa PDB memiliki tren positif denga angka rata-rata 17,3 persen pertahun sejak tahun 1990 sampai tahun 2014. Angka ini cukup berarti dan cukup besar karena menggunakan PDB harga berlaku. Penggunaan harga berlaku ketimbang harga konstan dengan tujuan agar perubahan PDB dan pajak dapat dibandingkan mengingat data pajak adalah menggunakan harga berlaku. 
Tabel 7 Hasil Regresi Tren PDB, 1990-2014

Dependent Variable: LOG(PDB_HB)

\begin{tabular}{crrrl}
\hline \hline Variable & Coefficient & Std. Error & t-Statistic & Prob. \\
C & 12.23193 & 0.039858 & 306.8840 & 0.0000 \\
@TREND & 0.172843 & 0.002847 & 60.70987 & 0.0000 \\
\hline \hline
\end{tabular}

R-squared

0.993798

Tren Pajak

Tren pajak tidak berbeda jauh dengan tren PDB. Bila dilihat tren pajak secara grafik seperti ditunjukkan pada gambar 4 nampak sedikit berfluktuasi tetapi meningkat terus. Pada tabel 8 ditunjukkan hasil regresi tren pajak dimana angka koefisien adalah sebesar 0,179 dan sangat berarti dengan tingkat signifikansi 0,00. Ini berarti tren pajak yang positif meningkat rata-rata 17,9 per tahun sejak tahun 1990 sampai tahun 2014. Dengan membandingkan tren pajak $(0,179)$ dengan tren $\operatorname{PDB}(0,173)$, maka diperoleh nilai tax buoyancy rata-rata sebesar $1,034(=0,179 / 0,173)$.

Tabel 8 Hasil Regresi Tren Pajak, 1990-2014 Dependent Variable: LOG(PAJAK)

\begin{tabular}{crrrc}
\hline \hline Variable & Coefficient & Std. Error & t-Statistic & Prob. \\
C & 9.918587 & 0.125084 & 79.29564 & 0.0000 \\
@TREND & 0.178595 & 0.008935 & 19.98930 & 0.0000 \\
\hline \hline R-squared & 0.945571 & & & \\
\hline \hline
\end{tabular}

Tax Ratio

Tax ratio (TR) merupakan perbandingan antara pajak dengan PDB harga berlaku. SEmakin tinggi TR berarti semakin tinggi kemampuan masyarakat membayar pajak seperti dijelaskan pada pendahuluan. TR Indonesia masih rendah dan lebih rendah dibandingkan dengan beberapa Negara tetangga di Indonesia, dimana TR Indonesia hanya 11,2 persen pada tahun 2013, lebih rendah dari TR Filipina. TR dipengaruhi oleh pertumbuhan pendapatan yang diukur dari pertumbuhan PDB berdasarkan harga konstan.
Tabel 9 menunjukkan bahwa angka koefisien pertumbuhan PDB adalah sebesar 0,799 dengan tingkat signifikansi 0,00. Ini menunjukkan bahwa setiap satu persen pertumbuhan ekonomi akan mampu meningkatkan TR sebesar 0,799 persen, tetapi tidak termasuk pertumbuhan PDB tahun 1998. Untuk pertumbuhan tahun 1998 digunakan variabel dumi yang juga sangat signifikan dan berbeda nyata dengan TR selain tahun 1998. Ini menunjukkan bahwa situasi politik yang buruk tahun 1998 membawa dampak buruk pada TR. Apabila 
regresi tidak menggunakan variabel dumi diperoleh koefisien pertumbuhan tidak signifikan. Koefisien determinasi relative rendah yang menunjukkan bahwa model ini hanya menjelaskan variasi TR sebesar 35 persen. Ini juga menandakan

Tabel 9 Hasil Regresi PDB terhadap Tax Ratio, 1990-2014

Dependent Variable: TR

\begin{tabular}{crrrl}
\hline \hline Variable & Coefficient & Std. Error & t-Statistic & Prob. \\
C & 6.453369 & 1.353205 & 4.768950 & 0.0001 \\
G_HK & 0.799065 & 0.230273 & 3.470073 & 0.0022 \\
DUMI & 14.75189 & 4.667801 & 3.160351 & 0.0045 \\
\hline \hline
\end{tabular}

R-squared

0.354210

\subsection{Pengaruh Pajak pada Pendidikan dan Kesempatan Kerja}

Pajak merupakan sumber penerimaan utama negara yang digunakan untuk membiayai pembangunan. Apabila penggunaan pajak diarahkan pada sasaran yang tepat maka akan dapat meningkatkan kesejahteraan masyarakat. Salah satu variabel penting dan juga merupakan sasaran pembangunan adalah meningkatkan pendidikan masyarakat. Untuk membiayai pendidikan pemerintah memerlukan dana yang cukup besar. Disamping itu, yang perlu dicermati apakah setiap satu rupia pajak yang dikeluarkan kembali untuk pembangunan apakah mampu meningkatkan pendidikan.

Pada tabel 10 disajikan hasil regresi pajak terhadap pendidikan

Tabel 10. Hasil Regresi Pajak terhadap Rata-rata Tahun Sekolah (MYS)
(MYS) yang diukur dari rata-rata tahun sekolah penduduk yang berumur 15 tahun ke atas seperti ditunjukkan pada tabel 5. Hasil regresi menunjukkan angka koefisien sebesar 0,122 dengan tingkat signifikansi 0,00. Ini menunjukkan bahwa untuk setiap kenaikan pajak satu persen akan menaikkan tingkat pendidikan sebesar 0,121 persen. Dengan pendidikan setinggi 8,4 tahun pada tahun 2014, maka kenaikan pajak satu persen akan menaikkan pendidikan sebesar ratarata satu tahun sekolah. Ini menunjukkan bahwa pajak telah mampu menaikkan tingkat pendidikan di Indonesia. bahwa situasi pada tahun 1998 sungguh buruk sehingga variasi TR tidak hanya dijelaskan oleh pertumbuhan ekonomi tetapi juga factor lain, seperti factor sosial dan politik.

Dependent Variable: LOG(MYS)

Variable

C
Coefficient

0.432694
Std. Error

0.166638
t-Statistic

2.596605
Prob.

0.0161 
Pengaruh pajak terhadap variabel kesempatan kerja juga dilakukan untuk melihat apakah pajak yang diterima oleh pemerintah dapat meningkatkan kesempatan kerja. Secara teoritis pajak yang dibelanjakan oleh pemerintah pada sasaran yang tepat seperti proyek pembangunan akan dapat menciptakan lapangan kerja baru bagi masyarakat sekitarnya, apabila tidak ini berarti pengeluaran pemerintah sia-sia saja.

Tabel 11 menunjukkan hasil regresi pajak terhadap kesempatan kerja (EMPL), dimana angka koefisien yang diperoleh adalah 0,096 dengan tingkat signifikansi 0,00. Ini menunjukkan bahwa untuk kenaikan setiap 1 persen pajak akan meningkan lapangan kerja sebesar

Tabel 11. Hasil Regresi Pajak terhadap Kesempatan Kerja (EMPL)
0,096 persen. Pada tahun 2015, angka kesempatan kerja adalah 115 juta orang yang berarti bahwa rata-rata apabila pajak meningkat satu persen maka kesempatan kerja yang bisa diciptakan adalah 11 juta orang. Persoalan besar bagi pemerintah adalah bagaimana meningkatkan pajak baik dengan cara intensifikasi maupun ekstensifikasi, bahkan telah dilakukan tax amnesty atau pengampunan pajak.

Pada model regresi ini variabel kesempatan kerja adalah jumlah orang yang bekerja dari tahun 1990 sampai tahun 2014, seperti ditunjukkan pada tabel 5. Pada tahun 1990 jumlah penduduk bekerja mencapai 73 juta orang dan meningkat menjadi hamper 115 juta pada tahun 2015.

Dependent Variable: LOG(EMPL)

\begin{tabular}{crrrc}
\hline \hline Variable & Coefficient & Std. Error & t-Statistic & Prob. \\
C & 17.17470 & 0.074713 & 229.8754 & 0.0000 \\
LOG(PAJAK) & 0.096253 & 0.006157 & 15.63261 & 0.0000 \\
\hline \hline
\end{tabular}

R-squared

0.913980

\subsection{Tax Buoyancy}

Tax Buoyancy (TB) adalah perbandingan antara pertumbuhan pajak dengan pertumbuhan pendapatan (PDB). Semakin tinggi pertumbuhan pajak dan lebih tinggi dari pertumbuhan PDB maka TB akan semakin tinggi pula. Ini bisa disebabkan karena dasar pajak yang semakin besar ditambah dengan wajib pajak yang semakin banyak dari tahun ke tahun sehingga penerimaan pajak semakin meningkat.

Untuk menaksir TB digunakan model Adaptive Expectation yang 
merupakan rasionalisasi daripada model Koyck. Rasionalisasi lainnya disampaikan oleh Marc Nerlove yang disebut stock adjustment model atau partial adjustment model (PAM). Adapun model yang dipakai adalah sbb.

$$
\begin{aligned}
& \text { Pajak }_{t}=\gamma \beta_{0}+\gamma \beta_{1} P D B_{t}+(1-\gamma) \text { Pajak }_{t-1} \\
& \text { atau } \\
& \text { Pajak }_{t}=\alpha_{0}+\alpha_{1} \text { PDB }_{t}+\alpha_{2} \text { Pajak }_{t-1}+v_{t}
\end{aligned}
$$

dimana:

$\alpha_{0}=\gamma \beta_{0}$

$\alpha_{1}=\gamma \beta_{1}$

$\alpha_{2}=(1-\gamma)$

$v_{t}=u_{t}-(1-\gamma) u_{t-1}$

Hasil regresi TB ditunjukkan pada tabel 12. Koefisien regresi PDB sebesar 0,872 relatif sedang dan sangat signifikan pada 0,00 . Angka ini menggambarkan TB jangka pendek yaitu pertumbuhan satu persen PDB mampu meningkatkan pajak sebesar 0,872 persen. Angka ini juga merupakan elastisitas penerimaan pajak selama periode 1990-2016. Namun, elastisitas ini meskipun positif dia bersifat inelastic karena lebih kecil dari satu. Sedangkan TB jangka panjang adalah sama dengan $0,872 /(1-0,156)$ atau sebesar 1,033. TB jangka panjang ini meskipun bersifat elastis, namun mendekati satu atau unitary dan tidak signifikan. Dengan demikian:

TB jangka pendek sebesar 0,872, dan bersifat inelastis, dan

TB jangka panjang sebesar 1,033, dan bersifat elastis

Hasil yang diharapkan adalah TB bersifat elastis sehingga setiap pertumbuhan PDB akan menghasilkan pertumbuhan pajak lebih besar daripada pertumbuhan PDB. Hasil ini menunjukkan bahwa pertumbuhan ekonomi belum bisa mendorong penerimaan pajak yang lebih besar.

Tabel 12 Hasil Regresi Tax Buoyancy, 1990-2014

Dependent Variable: LOG(PAJAK)

\begin{tabular}{crr}
\hline Variable & Coefficient & Std. \\
\hline \hline C & -2.278427 & 1.0 \\
LOG(PDB_HB) & 0.872145 & 0.2 \\
LOG(PAJAK(-1)) & 0.156224 & 0.2 \\
\hline
\end{tabular}

R-squared

0.935654

Ini bisa dimungkinkan karena ekonomi bawah tanah atau underground economy relatif cukup besar yang diperkiran mencapai 40 persen oleh Mantan Menkeu Prof Chatib Basri. Besarnya porsi ekonomi bawah tanah telah menyebabkan penerimaan pajak pemerintah berkurang. Yang tergolong dalam ekonomi bawah tanah juga meliputi pendapatan yang diperoleh secara illegal seperti polisi, pendapatan yang diperoleh secara legal namun tidak dilaporkan karena kesengajaan ataupun ketidaktahuan. Ketidaktahuan masyarakat untuk membayar pajak bisa disebabkan karena factor pendidikan yang rendah sehingga mereka tidak bisa menangkap informasi yang diberikan.

Rendahnya TB ditunjukkan pada gambar 6. Grafik itu juga menunjukkan bahwa TB tidak stabil sepanjang tahun 1990-2014 disamping menunjukkan tren yang datar. Fluktuasi yang besar dialami pada tahun 1998-2000 yaitu pada saat situasi sosial politik buruk sehingga tidak kondusif bagi pembangunan. 
Segmen grafik tersebut dalam jangka pendek dapat merefleksikan TB secara temporer atau jangka waktu relative pendek dimana koefsien elastisitasnya lebih rendah dari 1 (0,872), sedangkan dalam jangka panjang digambarkan oleh tren yang mendatar yang secara kuantitatif ditunjukkan oleh angka elastisitas yang mendekati 1 yaitu 0,033 .

\section{Gambar 6 Tax Buoyancy Indonesia, 1990-2014}

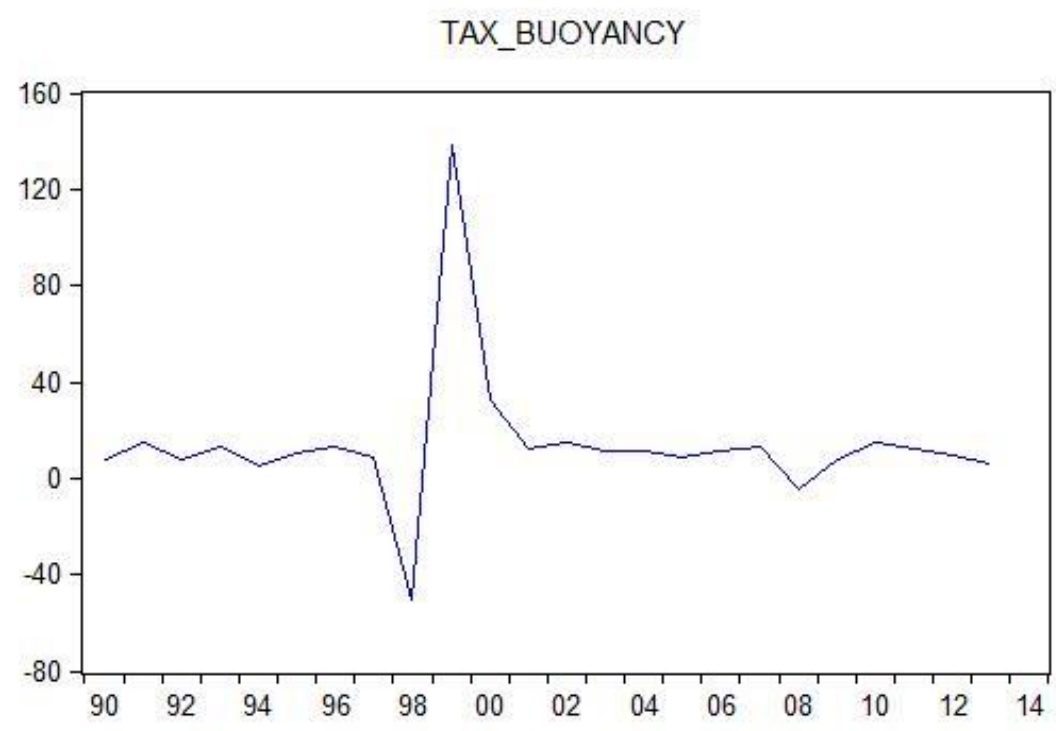

\subsection{Pengujian Model Stasioner}

Untuk menguji apakah model yang dibuat memenuhi persyaratan statsioner, yaitu model tersebut stabil maka digunakan tes Dicky-Fueler dalam tiga bentuk model persamaan sbb.

Dicky-Fueler Tests Model 1

Untuk

autokorelasi pada error term, ditambahkan variabel satu lag perbedaan pada variabel independen. Seperti ditunjukkan pada tabel 13, hasil regresi model 1 menghasilkan angka koefisien pajak(-1) sebesar 0,153 dengan nilai tau sebesar 3,89. Seperti ditunjukkan pada lampiran 6, nilai kritis Dickey-Fueler test pada tingkat signifikansi 5 persen adalah 1,95 untuk persamaan yang tidak menyertakan konstan. Dengan 
membandingkan nilai tau regresi dengan nilai kritis maka diperoleh 3,89>-1,95, yang berarti menerima

Tabel 13 Hasil Regresi Dickey-Fueler Test Model 1

Dependent Variable: D(PAJAK)

\begin{tabular}{crrrl}
\hline \hline Variable & Coefficient & Std. Error & t-Statistic & Prob. \\
PAJAK(-1) & 0.153438 & 0.039399 & 3.894499 & 0.0008 \\
D(PAJAK(-1) & -0.273329 & 0.252165 & -1.083930 & 0.2907 \\
\hline \hline
\end{tabular}

R-squared

0.257052 hipotesa nol dimana series tidak nonstasioner.

Dicky-Fueler Tests Model 2

Model 2 dibuat dengan memasukkan konstan pada model persamaan. Pada tabel 14 ditunjukkan hasil regresi dengan model tersebut dimana angka koefisien regresi untuk pajak(-1) adalah 0,126 dengan nilai tau sebesar 2,94. Nilai tau ini sangat signifikan dengan alpha kurang dari 5 persen atau 0,008. Seperti ditunjukkan pada lampiran 6, nilai kritis Dickey-Fueler test untuk model dengan konstanta dalam persamaan adalah -3 . Dengan membandingkan nilai tau sebesar 2,94 dan nilai kritis sebesar -3 , maka diperoleh nilai tau 2,94>-3, yang berarti hipotesa nol diterima yaitu series tidak non-stasioner

Tabel 14 Hasil Regresi Dickey-Fueler Test Model 2

Dependent Variable: D(PAJAK)

\begin{tabular}{crrrr}
\hline \hline Variable & Coefficient & Std. Error & t-Statistic & Prob. \\
C & 21117.96 & 14790.81 & 1.427776 & 0.1688 \\
PAJAK(-1) & 0.126266 & 0.042910 & 2.942584 & 0.0080 \\
D(PAJAK(-1)) & -0.313073 & 0.247721 & -1.263815 & 0.2208 \\
\hline \hline R-squared & 0.325774 & & \\
\hline \hline
\end{tabular}

Dicky-Fueler Tests Model 3

Pada model 3, ditambahkan konstanta dan tren untuk menguji apakah series non-stasioner dalm kurun waktu 25 tahun. Hasil regresi ditunjukkan pada tabel 15, dimana angka koefisien pajak(-1) adalah -0,024 dengan nilai tau sebesar 0,294 dan tidak signifikan pada alpha 5 persen atau 0,7722. Dengan membandingkan nilai tau ini dengan nilai kritis Dickey-Fueler seperti ditunjukkan pada lampiran 6 diperoleh hasilnya tidak berbeda dengan model 1 dan model 2 . Nilai kritis yang menggunakan konstanta dan tren adalah sebesar $-3,60$. Dengan membandingkan ke dua angka ini,nilai tau -0,024>-3,60 yang berarti hipotesa nol diterima dan series tidak non-stasioner. Namun, implikasi hasil ini adalah bahwa 
pajak tahun sebelumnya akan menurunkan penerimaan pajak saat ini, hal mana berbeda dengan model 1 dan model 2 dimana pajak sebelumnya berpengaruh positip pada penerimaan pajak saat ini. Mengingat data agregat pajak yang diperoleh selama 25 tahun meningkat terus maka model 1 dan model 2 lebih memiliki arti ekonomi. Disamping itu koefisien pajak(-1) sebesar -0,024 secara statistic tidak signifikan.

Tabel 15 Hasil Regresi Dickey-Fueler Test Model 3

Dependent Variable: D(PAJAK)

\begin{tabular}{crrrc}
\hline \hline Variable & Coefficient & Std. Error & t-Statistic & Prob. \\
C & -33220.92 & 29323.43 & -1.132914 & 0.2713 \\
PAJAK(-1) & -0.024088 & 0.082009 & -0.293727 & 0.7722 \\
D(PAJAK(-1)) & -0.325527 & 0.229150 & -1.420582 & 0.1716 \\
@TREND & 8073.446 & 3853.796 & 2.094934 & 0.0498 \\
\hline \hline R-squared & 0.452288 & & \\
\hline \hline
\end{tabular}

Pengujian Order of Integration

Untuk melihaat sampai berapa kali perbedaan dalam time series suatu variabel dapat dilakukan, maka dilakukan tes order of integration dengan menggunakan Dickey-Fueler test. Tes ini dilakukan terhadap perbedaan pada variabel pajak tanpa menyertakan konstanta. Tabel 16 menunjukkan hasil tes tersebut dimana perbedaan variabel pajak order satu (D(PAJAK(-1))) menghasilkan koefisien angka sebesar -0,469 dengan nilai tau -2,528 dan signifikan pada tingkat 0,019. Dengan membandingkan dengan nilai kritis sebesar $-1,95$ seperti ditunjukkan pada lampiran 6, maka diperoleh hasil -2,528<-1,95 yang berarti hipotesa nol ditolak dan menerima hipotesa alternative bahwa perbedaan pajak adalah stasioner.

Tabel 16 Hasil Regresi Uji Order Integrasi

Dependent Variable: D(D(PAJAK))

\begin{tabular}{ccccc}
\hline \hline Variable & Coefficient & Std. Error & t-Statistic & Prob. \\
\hline \hline D(PAJAK(-1)) & -0.469158 & 0.185581 & -2.528054 & 0.0192 \\
R-squared & 0.223855 & & & \\
\hline \hline
\end{tabular}

\subsection{Pengujian Kointegrasi-the Augmenten Engle-Granger Cointegration Test}

Kointegrasi mengandung arti bahwa pajak dan PDB memiliki tren stokastik yang serupa, dan karena perbedaan error adalah stasioner maka ke dua variabel 
tersebut yaitu pajak dan PDB tidak berbeda arah terlalu jauh satu dengan lainnya. Untuk menguji kointegrasi dilakukan pada tiga model, yaitu model 1 adalah persamaan tanpa menggunakan konstanta, model 2 adalah persamaan yang menggunakan konstanta, dan model 3 adalah persamaan yang menggunakan konstanta dan tren.

Hipotesa nol dan alternative dalam tes kointegrasi ditetapkan sbb.

H0: series tidak terkointegrasi, yaitu residual non-stasioner,

$\mathrm{H} 1$ : series terkointegrasi, yaitu residual stasioner.

Apabila tau sama atau lebih kecil dari tau statistic, maka tolak H0.

Kointegrasi Model 1

Pada tabel 17 ditunjukkan hasil regresi PDB atas pajak, dimana model ini tidak menyertakan konstanta. Pada tabel 18 diperlihatkan hasil regresi tes kointegrasi Model 1. Pada tabel 18, koefisien angka residual (RES_COIN_1(-1)) adalah -0,503 dengan nilai tau sebesar -2,164. Nilai kritis pada tingkat 5 persen adalah -3,461 seperti ditunjukkan pada lampiran 7. Dengan membandingkan ke dua angka ini, dimana -2,164>-3,461, maka hipotesa nol tidak ditolak bahwa residual regresi non-stasioner yang berarti bahwa residual non-stasioner.

Tabel 17 Hasil Regresi PDB atas Pajak tanpa Konstanta

Dependent Variable: LOG(PAJAK)

\begin{tabular}{ccccr}
\hline \hline Variable & Coefficient & Std. Error & t-Statistic & Prob. \\
\hline \hline LOG(PDB_HB) & 0.844516 & 0.005641 & 149.7177 & 0.0000 \\
R-squared & 0.910221 & & & \\
\hline \hline
\end{tabular}

Tabel 18 Hasil Regresi Kointegrasi Model 1

Dependent Variable: D(RES_COIN_1)

\begin{tabular}{crrrr}
\hline \hline Variable & Coefficient & Std. Error & t-Statistic & Prob. \\
RES_COIN_1(-1) & -0.503245 & 0.232510 & -2.164403 & 0.0421 \\
D(RES_COIN_1(-1)) & -0.122869 & 0.216966 & -0.566306 & 0.5772 \\
\hline \hline R-squared & 0.295210 & & & \\
\hline \hline
\end{tabular}

Kointegrasi Model 2

Pada tabel 19 ditunjukkan hasil regresi PDB atas pajak dengan menyertakan konstanta, dan pada tabel 20 diperlihatkan hasil regresi tes kointegrasi Model 2. Pada tabel 20, koefisien angka residual (RES_COIN_2(-1)) adalah $-0,817$ dengan nilai tau sebesar $-3,867$. Nilai kritis pada tingkat 5 persen adalah $-3,00$ seperti ditunjukkan pada lampiran 7 . Dengan membandingkan ke dua angka ini, dimana $-3,867<-3,461$, maka hipotesa nol ditolak bahwa residual regresi non-stasioner yang berarti bahwa residual stasioner.

Tabel 19 Hasil Regresi PDB atas Pajak dengan Konstanta 
Dependent Variable: LOG(PAJAK)

\begin{tabular}{crcrr}
\hline Variable & Coefficient & Std. Error & t-Statistic & Prob. \\
C & -2.632310 & 0.775909 & -3.392549 & 0.0025 \\
LOG(PDB_HB) & 1.027121 & 0.054030 & 19.01002 & 0.0000 \\
R-squared & 0.940164 & Mean dependent var & & 12.06173 \\
\hline \hline
\end{tabular}

Tabel 20 Hasil Regresi Kointegrasi Model 2

Dependent Variable: D(RES_COIN_2)

\begin{tabular}{crccr}
\hline Variable & Coefficient & Std. Error & t-Statistic & Prob. \\
RES_COIN_2(-1) & -0.817110 & 0.221638 & -3.686690 & 0.0015 \\
D(RES_COIN_1(-2)) & -0.028702 & 0.171934 & -0.166937 & 0.8691 \\
R-squared & 0.413780 & Mean dependent var & & -0.007402 \\
\hline \hline
\end{tabular}

Kointegrasi Model 3

Pada tabel 21 ditunjukkan hasil regresi PDB atas pajak dengan menyertakan konstanta dan tren, dan pada tabel 22 diperlihatkan hasil regresi tes kointegrasi Model 3. Pada tabel 22, koefisien angka residual (RES_COIN_3(-1)) adalah $-0,975$ dengan nilai tau sebesar $-4,303$. Nilai kritis pada tingkat 5 persen adalah -3,461 seperti ditunjukkan pada lampiran 7. Dengan membandingkan ke dua angka ini, dimana $-4,303<-3,461$, maka hipotesa nol ditolak bahwa residual regresi non-stasioner yang berarti bahwa residual stasioner.

Tabel 21 Hasil Regresi PDB atas Pajak dengan Konstanta dan Tren Dependent Variable: LOG(PAJAK)

\begin{tabular}{crrrr}
\hline \hline Variable & Coefficient & Std. Error & t-Statistic & Prob. \\
C & 9.426996 & 8.184286 & 1.151841 & 0.2618 \\
LOG(PDB_HB) & 0.040189 & 0.669010 & 0.060073 & 0.9526 \\
@TREND & 0.171649 & 0.115994 & 1.479807 & 0.1531 \\
R-squared & 0.945580 & & & \\
\hline \hline
\end{tabular}

Tabel 22 Hasil Regresi Kointegrasi Model 3

Dependent Variable: D(RES_COIN_3)

\begin{tabular}{crrrr}
\hline \hline Variable & Coefficient & Std. Error & t-Statistic & Prob. \\
RES_COIN_3(-1) & -0.974915 & 0.226585 & -4.302649 & 0.0003 \\
D(RES_COIN_3(-2)) & -0.033469 & 0.161274 & -0.207527 & 0.8377 \\
\hline \hline
\end{tabular}

R-squared

0.483564

\subsection{Prospek Pajak dan Pertumbuhan Ekonomi Ekonomi}


Prospek penerimaan pajak ditaksir dengan menggunakan bebeapa variabel penting, yaitu: pendidikan, proporsi pendapatan sektor pertanian, pengangguran, dan pertumbuhan ekonomi. Pendidikan diukur dari rata-rata tahun sekolah penduduk berumur 15 tahun ke atas. Hasil yang diharapkan adalah semakin tinggi pendidikan maka penerimaan pajak semakin besar pula dengan alasan bahwa mereka yang semakin terdidik akan lebih sadar untuk membayar pajak, disamping pendidikan yang semakin tinggi akan membuat pendapatannya juga semakin meningkat. Peranan sektor pertanian diukur dari porsi pendapatan yang disumbangkan oleh sektor ini pada PDB total. Sumbangan sektor non-pertanian tidak diikutkan dalam regresi karena akan mengakibatkan kolinearitas sempurna. Disamping itu, menggunakan sektor pertanian sebagai regresor akan menunjukkan sampai sejauh mana peran sektor pertanian dalam meningkatkan pajak mengingat di sektor ini banyak terdapat penagngguran tidak kentara disampin produktivitas tenaga kerjanya rendah. Pengangguran digunakan untuk menaksir bahwa mereka yang tidak mendapat pekerjaan sudah dipastikan tidak akan membayar pajak yang berarti main tinggi penagngguran maka pajak akan smakin rendah.Pertumbuhan ekonomi digunakan sebagai regresor mengingat pertumbuhan ekonomi menggambarkan kemampuan masyarakat dalam bidang ekonomi dalam bentuk daya beli yang semakin meningkat. Hasil yang diharapkan adalah hubungan yang positif yaitu semakin tinggi pertumbuhan ekonomi maka penerimaan pajak juga semakin tinggi.

Hasil regresi berganda ditunjukkan pada tabel 23. Hasil yang diperoleh seperti yang diharapkan, yaitu pendidikan (MYS) memiliki hubungan positif dengan pajak dengan angka koefisien sebesar 0,776 dan sangat signifikan yang lebih rendah dari 0,05. Angka ini menunjukkan bahwa setiap kenaikan pendidikan rata-rata satu tahun akan meningkantkan penerimaan pajak sebesar 0,776 persen, rata-rata dalam kurun waktu 25 tahun. Variabel sektor pertanian (Y_A) memiliki hubungan negative seperti yang diduga dengan angka koefisien sebesar -0,290 dan siginikan pada 0,0003 . Angka ini menunjukkan bahwa peningkatan sumbangan sektor pertanian akan menurunkan penerimaan pajak sebesar 0,29 persen. Ini bisa disebabkan karena petani masih sebagian besar subsisten dimana produksinya adalah untuk langsung dikonsumsi sehingga peningkatan produksi semata-mata untuk konsumsi tanpa cukup untuk ditabung atau pendapatan yang diperoleh dibawah batas kena pajak. Hal yang sama juga diperoleh untuk variabel pengangguran (UNEMP) sebesar -0,127 dan siginifikan pada 0,043 . Ini juga menunjukkan bahwa setiap pertambahan pengangguran satu persen akan menurunkan penerimaan pajak sebesar 0,127 persen. Ini berarti bahwa program pemerintah yang harus didorong terus adalah penciptaan lapangan kerja sehingga kemiskinan bisa dikurangi. Dengan demikian, daya beli bisa meningkat dan pada 
akhirnya kemampuan membayar pajak tercipta. Variabel pertumbuhan ekonomi (G_HK) memiliki hubungan positif seperti yang diharapkan, namun hubungan ini tidak signifikan

Tabel 23 Hasil Regresi Berganda Terhadap Pajak

Dependent Variable: LOG(PAJAK)

\begin{tabular}{ccccc}
\hline \hline Variable & Coefficient & Std. Error & t-Statistic & Prob. \\
\hline \hline C & 12.07651 & 2.352827 & 5.132766 & 0.0001 \\
MYS & 0.776462 & 0.175781 & 4.417209 & 0.0003 \\
Y_A & -0.289863 & 0.080393 & -3.605554 & 0.0018 \\
UNEMP & -0.126622 & 0.058717 & -2.156479 & 0.0434 \\
G_HK & 0.022941 & 0.026967 & 0.850700 & 0.4050 \\
\hline \hline
\end{tabular}

R-squared

0.912085

\section{KESIMPULAN DAN SARAN}

\section{Kesimpulan}

1. Keadaan ekonomi Indonesia dalam kurun waktu 25 tahun sejak tahun 1990 sampai 2014 menunjukkan tren yang meningkat bila dilihat dari beberapa besaran angka agregat makro, yaitu pendapatan (PDB), penerimaan pajak, kesempatan kerja, dan pendidikan, kecuali pada tahun 1998-2000 yang diselingi oleh disrupsi karena factor sosial dan politik yang berdampak buruk bagi ekonomi.

2. Penerimaan pajak menunjukkan tren yang positif namun pertumbuhannya masih kecil dan hanya sedikit di atas pertumbuhan pendapatan (PDB). Ini telah membuat tax buoyancy untuk mampu meningkatkan pajak. Angka koefisien diperoleh sebesar 0,023 tetapi tidak signifikan dengan alpha sebesar 0,405. 
kontribusinya pada pendapatan nasional, dan pengangguran. Kedua variabel ini secara signifikan mengurangi penerimaan pajak.

5. Model time series yang digunakan untuk mengukur perilaku pajak selama kurun waktu 25 tahun secara statistic bagus karena baik variabel lag maupun residual pada model persamaan semuanya stasioner, yang berarti model stabil untuk digunakan memprediksi penerimaan pajak.

\section{Saran}

1. Untuk meningkatkan penerimaan pajak, pemerintah hendaknya meningkatkan pendidikan masyarakat. Pendidikan akan membuka cakrawala masyarakat terhadap pentingnya pajak, dan kesadaran mereka bahwa pajak memang sangat diperlukan untuk membiayai pembangunan. Peningkatan pendidikan akan bisa mengurangi ekonomi bawah tanah yang porsinya di Indonesia relative masih besar, dimana porsi yang besar ini telah mengurangi potensi pajak yang bisa direalisasikan.

2. Saran lainnya yang dapat disampaikan adalah kebijakan penguatan peran sektor pertanian agar sektor ini bisa meningkatkan

produktivitasnya. Kenaikan produktivitas akan meningkatkan pendapatan mereka, sehingga petani dalam jangka panjang memiliki pendapatan yang cukup untuk mampu membayar pajak.

3. Kebijakan penting lainnya adalah dengan menciptakan kesempatan kerja yang lebih agar mereka memiliki daya beli sehingga dalam jangka panjang memiliki pendapatan yang cukup untuk membayar pajak.

\section{TINJAUAN PUSTAKA}

1. Azwar, P. and Rod Tyers.May. (2015). Indonesian Macro Policy through Two Crises. Centre for Applied Macroeconomic Analysis. Australian National University.

2. Bikas, E. and Emelie Andruskaite. (2013). Factors Affecting Value Added Tax Revenue. $1^{\text {st }}$ Annual International Interdisciplinary Conference, AIIC. 2013, 24-26 April. Proceedings.

3. BI. Statistik dan Keuangan Indonesia. http://www.bi.go.id

4. Brodjonegoro, B. May. (2013). Indonesia Fiscal Policy: Stimulus in the crisis time $\mathcal{E}$ long term development. United Nations. ESCAP.

5. Castro, G.A. and Diama Berenice Ramirez Camarillo. (2014). Determinants of tax revenue in OECD countries over the period. (2001-2011). Contraduria y Administracion 59(3), Julio-septiembre 2014:35-59.

6. DJA, 2016. Informasi APBN 2016. Kementerian Keuangan Indonesia.

7. IMF. February 23, (2015). Indonesia Selected Issues. 
8. Karagoz, K. (2013). Determinants of Tax Revenue: Does Sektorial Composition Matter? Journal of Finance, Accounting and Management, 4(2), 50-63, July 2013

9. Mankiw, N.G., (2015). Seventh Edition. Principles of Economics. Cengage Learning. Stamford. USA.

10. Nizar, M.A. and Kuntarto Purnomo, (2011). Underground Economy Activities in Indonesia. MPRA Paper No.65608.

11. Siwage Dharma Negara. (2016). Indonesia's 2016 Budget: Optimism Amidst Global Uncertainties. Perspective. Issue:2016 No.3. ISEAS.

12. The World Bank. (2015). Indonesia Economic Quarterly: Slower Gains.

13. Treasury. 2016. APBN 2016: Percepatan Pembangunan Infrastruktur, Perkuatan Pondasi Pembangunan yang Berkualitas.Kementerian Keuangan Indonesia.

14. Cromwell, J. N., Michael J. Hannan, Walter C. Labys, Michel Terraza. (1994). Multivariate Tests for Time Series Models. Series: Quantitative Applications in the Social Sciences. Sage Publications, Inc. California.

15. Dougherty, C. (2002). Introduction to Econometrics. Oxford University Press. Auckland.

16. Enders, W. (2004). Applied Econometric Time Series. John WILEY \& Sons, Inc. USA.

17. Griffiths, W., R. Carter Hill, George G. Judge. (1993). Learning and Practicing Econometrics. John Wiley \& Sons, Inc. New York.

18. Gujarati, D. N. (2003). Basic Econometrics. McGraw-Hill. New York.

19. Heij, C., Paul de Boer, Philip Hans Franses, Teun Kloek, Herman K. Van Dijk. 2004. Econometric Methods with Applications in Business and Economics. Oxford University Press. Oxford.

20. Patterson, K. (2000). An Introduction to Applied Econometrics: a time series approach. PALGRAVE. New York.

21. Thomas, R. L. (2000). Modern Econometrics. Addison-Wesley Longman Limited. Edinburg Gate. 